\title{
Hydrochemical peculiarities and groundwater quality assessment of the Birimian and Tarkwaian aquifer systems in Bosome Freho District and Bekwai Municipality of the Ashanti Region, Ghana
}

\author{
Louis Boansi Okofo ${ }^{1}$ (D) Nana Akyerefi Anderson ${ }^{2} \cdot$ Kenneth Bedu-Addo $^{3} \cdot$ Ekua Afrakoma Armoo $^{4}$
}

Received: 26 October 2020 / Accepted: 1 November 2021 / Published online: 29 November 2021

(c) The Author(s) 2021

\begin{abstract}
The Birimian and Tarkwaian aquifer systems are the main sources of water supply for the Bosome Freho District and Bekwai Municipality inhabitants in the Ashanti region of Ghana. A hydrogeochemical assessment was carried out to ascertain the natural baseline chemistry of the groundwaters and the factors influencing groundwater chemistry in these two areas. A multivariate statistical tool consisting of principal component analysis (PCA) and hierarchical cluster analysis (HCA) together with hydrochemical graphical plots was applied on 64 groundwater samples. The Q-mode HCA results were used to explain the changes in groundwater chemistry along the flow paths where three spatial groundwater zones and water types were delineated. The first type consists of $\mathrm{Ca}-\mathrm{Mg}-\mathrm{HCO}_{3}$ freshwater (recharge zone), which transitions into $\mathrm{Ca}-\mathrm{Na}-\mathrm{HCO}$ or $\mathrm{Na}-\mathrm{Ca}-\mathrm{HCO}_{3}$ mixed waters (intermediate zone) and finally evolves to the third type of $\mathrm{Na}-\mathrm{Ca}-\mathrm{Mg}-\mathrm{HCO}{ }_{3}-\mathrm{Cl}$ water (discharge zone). The study also reveals that the natural process influencing water chemistry is groundwater-rock interaction from carbonate and silicate weathering/dissolution, aided by carbonic acid from precipitation and releases concentration of $\mathrm{Na}^{+}, \mathrm{Ca}^{2+}, \mathrm{Mg}^{2+}$, and $\mathrm{HCO}_{3}{ }^{-}$into the groundwaters significantly. The chloro-alkaline indices also reveal cation exchange as the principal natural factor that controls groundwater chemistry in the area. Inverse geochemical modelling shows the dissolution of primary minerals such as dolomite, plagioclase, halite, gypsum, and precipitation of calcite and chlorite along the groundwater flow path. Anthropogenic activities have little influence on groundwater chemistry. The quality of groundwater in the Bosome Freho District and Bekwai Municipality is suitable for irrigational use and drinking water consumption. The results obtained so far will contribute to research paucity in the study area and serve as a guide for decision-makers for improved water resources management.
\end{abstract}

Keywords Natural baseline chemistry $\cdot$ Birimian aquifer system $\cdot$ Chloro-alkaline indices $\cdot$ Inverse geochemical modelling

This article is part of a Topical Collection in Environmental Earth Sciences on Groundwater quality and contamination and the application of GIS, guest edited by Narsimha Adimalla and Hui Qian.

Louis Boansi Okofo

okofols2000@yahoo.com

1 Institute of Environmental Technology and Process Engineering, Chair of Biotechnology of Water Treatment, Brandenburg University of Technology, Senftenberg, Cottbus, Germany

2 Bauer Engineering Ghana Ltd, 6 Cotton Street, East Legon, Accra, Ghana

3 School of Engineering and Architecture, SRH Hochschule Heidelberg, Heidelberg, Germany

4 Council for Scientific and Industrial Research, Institute of Industrial Research, 92 Boundary Rd, Accra, Ghana

\section{Introduction}

Increasing urbanisation as a result of rapid population growth in most African cities imposes a tremendous challenge on the available and future water resources. Since the year 2000, when the majority of the world's population became urbanised, a gamut of international, regional, local, government, and non-governmental organisations spearheaded by the United Nations have dedicated strengths and resources to examining how sustainable water could be provided in the wake of the global climatic changes and increasing population, especially in developing countries (Cobbinah et al. 2016). Arguably, the most ambitious is the formulation of United Nations Sustainable Development Goals 6 (SDGs) as a stand-alone goal to ensure that clean water use and sanitation practice become basic and universal to humanity (UN 
2010). However, in recent years, there has been a mismatch between water supply and demand in urban cities of Ghana as a result of increasing population demand. Urban water supply in Ghana (about 62\%) is through pipe-borne water, distributed by Ghana Water Company Limited (GWCL) (Ghana Statistical Service 2014). The water supply by GWCL is mostly irregular, inadequate, and within selected geographical settings. Furthermore, with the increasing call for wider water coverage and distribution due to growing population demand, the water supply in the future remains uncertain (Cobbinah et al. 2016; Adimalla 2020a, 2021).

The Bosome Freho District and Bekwai Municipality are characterised by the current paradigm of mixed areas of urban and rural dwellers. About $68 \%$ of the households in the Bekwai municipality use borehole water, while $32 \%$ use pipe-borne water. The Bosome Freho district is primarily rural, for which reason GWCL water coverage is virtually non-existent; the public water supply is exclusively through borehole water, with few communities around the Lake Bosumtwi using the lake water for domestic purposes (Ghana Statistical Service 2014). In addition, the majority of the population in the study area are into crop farming, in which groundwater is used for irrigation. The use of groundwater for domestic purposes and the farmers' eagerness to upscale their large irrigational farms warrant a complete understanding of groundwater for improved aquifer management (Anim-Gyampo et al. 2018; Adimalla et al. 2020b, 2021).

The Birimian and Tarkwaian aquifer systems are the major sources of public water consumption in the study area. The interactions between these rocks and water often lead to mineral dissolution revealing groundwater properties such as aggressive carbon dioxide, colour, hardness, and total dissolved solids (TDS) (Karro et al. 2009; Adimalla et al. 2020b). With this in mind, the solute concentrations can be inferred to determine the major ions and trace metals contained in groundwater. This can help to analyse the baseline water chemistry and design pollution trends of which future water quality changes can be deduced and predicted (Raiber et al. 2012). Noteworthy studies of groundwater chemistry have shown that a basic knowledge of the natural processes that control water chemistry is essential for the understanding of groundwater quality (Hem 1985; Appelo and Postma 2005).

In the Ashanti region of Ghana, a considerable number of water quality assessment studies have been reported by various researchers. Tay et al. (2018) characterised the hydrochemistry of groundwater and surface water in mining communities of Amansie and Adansie Districts in the Ashanti region. The results indicated that low acidic groundwater and silicate weathering are the main natural factors controlling groundwater chemistry in the area. A study on groundwater quality by Nkansah and Ephraim (2009) in the
Ejisu-Juaben and Bosomtwi-Atwima Kwanwoma Districts in the Ashanti region of Ghana also revealed that the physicochemical parameters and trace metals were all within the acceptable limits for drinking water. Notwithstanding the numerous groundwater quality studies in the region, the use of multivariate statistics to elucidate the natural factors controlling groundwater chemistry has received little attention, for which reason there is a paucity of research. In contributing to addressing this research paucity, multivariate statistical methods such as hierarchical cluster analysis (HCA) and principal component analysis (PCA) are unique tools used to assemble water chemistry into distinct clusters aiding in scientifically robust inferences such as anthropogenic and geogenic origins of the water chemistry (Kim et al. 2014; Adimalla et al. 2018). The present study set out to (1) investigate the natural and anthropogenic factors controlling groundwater chemistry in the Bosome Freho District and Bekwai Municipality; (2) ascertain the natural baseline water chemistry in the aquifers study area. The results obtained will be helpful to understand the hydrogeochemical process for improved aquifer management.

\section{Study area}

The study area consists of two administrative areas; the Bosome Freho District and the Bekwai Municipality formerly called the Amansie East District. These areas are located in the south-eastern part of the Ashanti region of Ghana. The Bosome Freho District is approximately 95\% rural settings, and water supply is mainly through groundwater wells fitted with handpumps (Ghana Statistical Service 2014). The landforms of the study area are forest dissected plateau characterised by flat and undulating topographical elevations ranging between 721 m.a.s.l and 91 m.a.s.l. (Fig. 1). Lake Bosumtwi, a natural crater lake formed as a result of meteorite impact ca. $1.07 \mathrm{Ma}$, is centred in the northeastern part of the study area (Elbra et al. 2007). The Lake forms a circular hydrological basin believed to be recharging the aquifers in the area. Several rivers and tributaries such as the Pra, Anum, Sunso, Fre, and Oda rivers form dendritic drainage patterns in the study area (Ghana Statistical Service 2014).

The area belongs to a semi-equatorial climatic zone, which generally consists of two rainfall seasons. The major rainfall season begins from March to July, while the minor rainfall season lasts only 3 months, from September to October. The rainfall amount ranges between 1600 and $1800 \mathrm{~mm}$, with an average annual precipitation of $1550 \mathrm{~mm}$. The groundwater recharge is usually $30-35 \%$ of the total precipitation in the area. The relative humidity is very moderate in the area, but can be high as $70 \%$ during the rainy season. Potential evapotranspiration rates in the region have been reported to range from 60 to $80 \%$ (Amu-Mensah et al. 2019). The mean annual temperature ranges between $20^{\circ} \mathrm{C}$ 


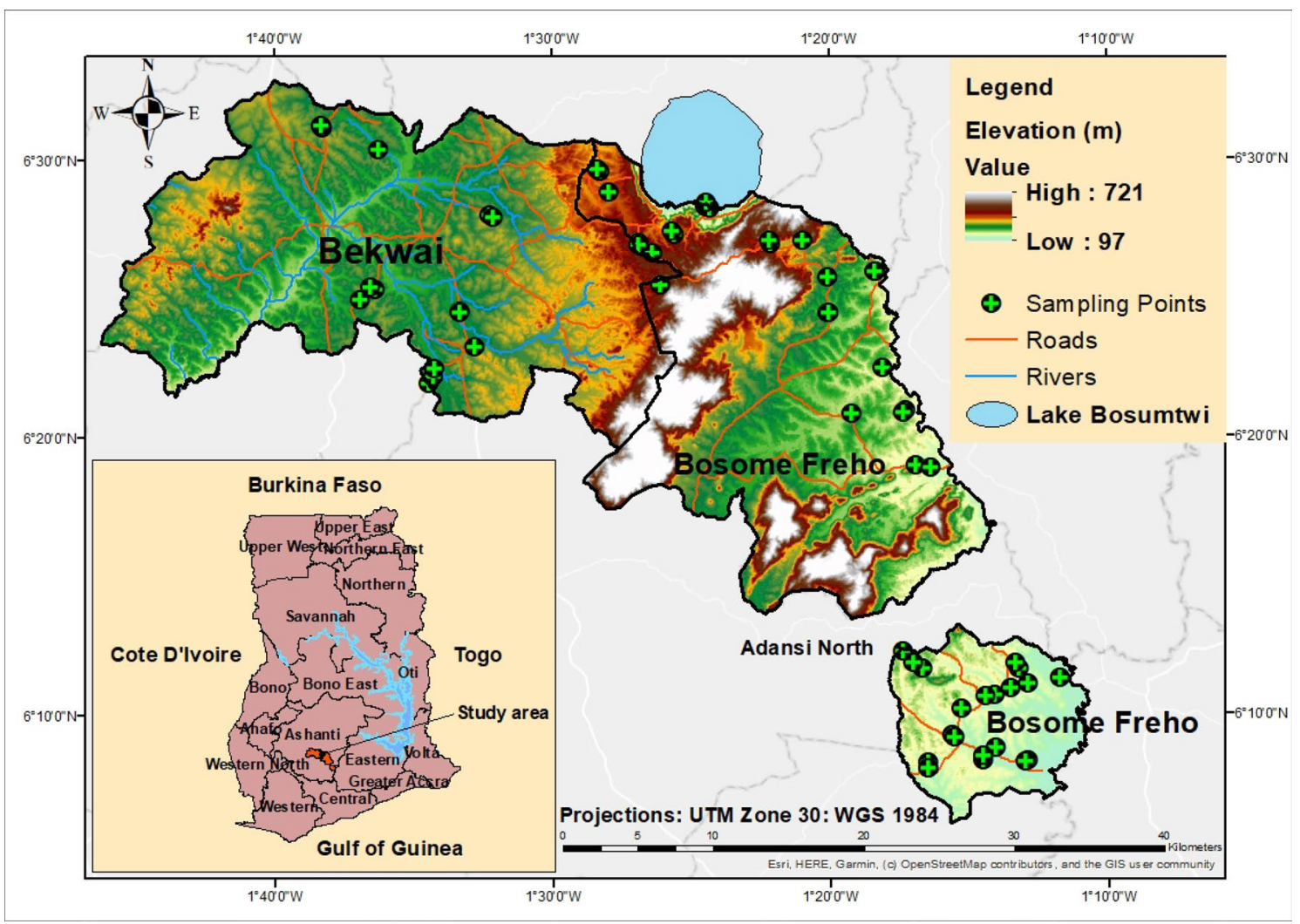

Fig. 1 The study area showing the two administrative areas with the sampling points

and $32{ }^{\circ} \mathrm{C}$ with an average of $25^{\circ} \mathrm{C}$. This together with the rainfall patterns boost agricultural food production in the area (Ghana Statistical Service 2014).

The vegetation in the study area is a semi-deciduous forest, mainly of economic trees such as Wawa, Odum, Sapele, and Mahogany. The dominant vegetation cover in the district is the Akyeampong shrub (Chronolaena Ordorata), which serves as raw materials for domestic and industrial uses. The area is overlain by three soil types derived from the weathering of the Birimian and the Tarkwaian rocks. The ferric acrisols is the predominant soil found in the study area (Fig. 2). The haplic and gleylic alisols soils are found in small portions of the study area, with the latter found in areas around Lake Bosumtwi. The ferric lixisols soil is overlain in the southern part of the area. There are also accepted local soil classification that supports cocoa trees, oil palm trees, and quarrying. They are the Asikuma-Atewu Ansum compound soil, Bekwai-Oda compound soil, the KobedaAmuni Bekwai simple soil, and the Juaso-Manso association soil (Ghana Statistical Service 2014).

\section{Regional and local geology}

The study area is underlain by rocks of the Birimian Supergroup and the Tarkwaian Group (Fig. 3). The Birimian
Supergroup is predominantly found in the study area and consists of metamorphosed sedimentary and volcanic rocks (SNC-Lavalin/INRS 2011). These rock units exhibited lowgrade metamorphism and were formed contemporaneously during the early Proterozoic era $2166 \pm 66 \mathrm{Ma}$ (Leube et al. 1990), invalidating the earlier studies by other researchers that the metavolcanic rocks were younger than metasedimentary rocks (Moon and Mason 1967). Studies by Leube et al. (1990) show that Birimian metasedimentary rocks are made up of chemical sediments, volcaniclastics, and argillitic rocks. These rock units have metamorphosed now into rock types such as phyllites, schists, shale, and metagraywackes. The Birimian metavolcanic rocks, commonly called greenstones, on the other hand, consist of basalt and minor interbedded volcaniclastics rocks, which have metamorphosed into amphibolites and calcite-chlorite schist. Evidence of petrographical and geochemical studies done by Karikari et al. (2007) around Lake Bosumtwi and its surrounding areas revealed that the lithologies are dominated by quartz, feldspar, micas carbonates, Fe oxides, and chlorite. Mumin and Fleet (1994) also found out carbonate minerals such as calcite, magnesite, siderite, and ankerite in different amounts in the Birimian rocks of the Ashanti Gold Belt, Ghana. The Birimian rocks are folded and intruded by the Eburnean Plutonic Suite, mainly granitoid formed during 


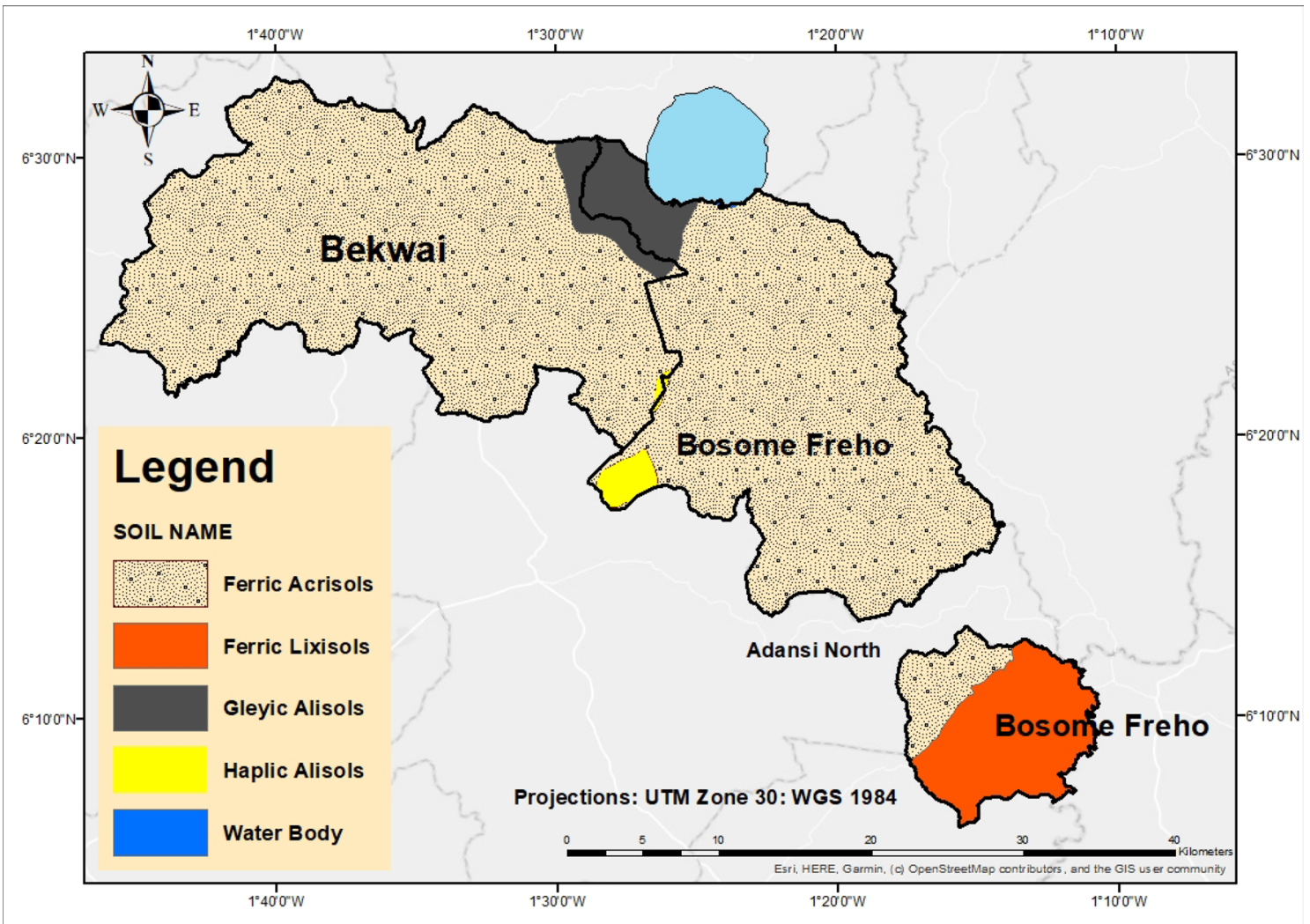

Fig. 2 The various soil types that underlay the study area

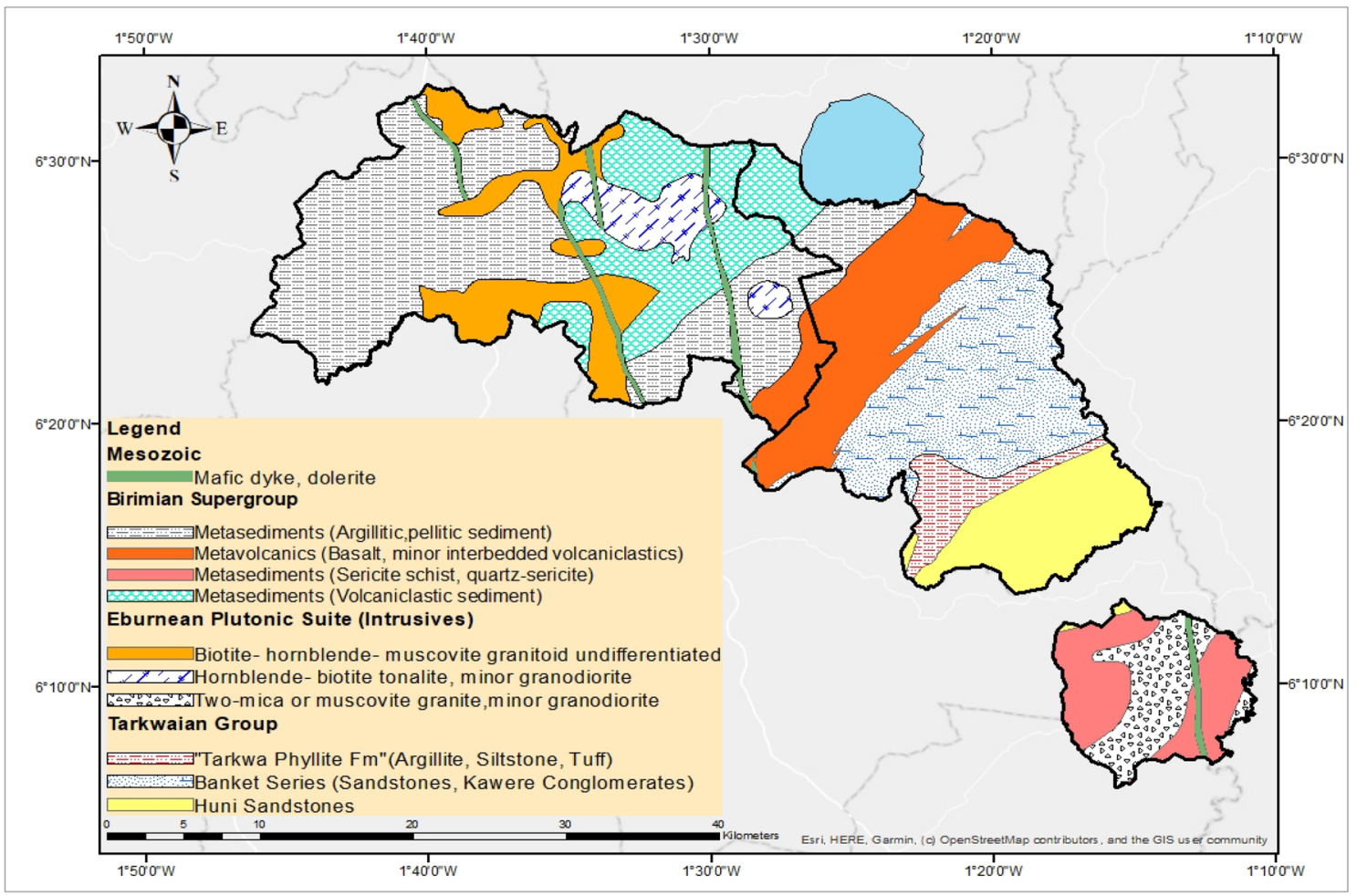

Fig. 3 The geology map of the study area 
the Eburnean Orogeny of the Paleoproterozoic era approximately 2150-2070 Ma (Feybesse et al. 2006). This intrusive is composed of muscovite granite, biotite-hornblende granitoid, minor granodiorite, and locally coarse-grained leucogranite (SNC-Lavalin/INRS 2011). The intrusive granites in the area are rich in minerals such as quartz, biotite, alkali feldspar, plagioclase feldspar, muscovite, and chlorite (Karikari et al. 2007). The Tarkwaian Supergroup is found in the south-eastern part of the study area and lies unconformably on the Birimian rocks. These are clastic sedimentary rocks that originate from the Birimian and associated granitoid during the Eburnean Orogeny in the Ashanti Belt. The rocks were eroded and uplifted, filling a large graben of the Tarkwaian rocks. The thickness of the Tarkwaian rocks within the Ashanti Belt is circa $2500 \mathrm{~m}$ with an approximate age of 2133-2132 Ma (Hirdes and Nunoo, 1994; Smith et.al. 2016). The Tarkwaian rocks are divided into: the Tarkwa Phyllite, Banket Series, and the Huni Sandstones. The Banket Series comprises sandstones and conglomerates with minor grits and overlain by the Tarkwa Phyllite, which consists of argillites, siltstones, and tuffs. The Huni sandstones comprise uniform sandstones and are the uppermost layer of the Tarkwaian group (SNC-Lavalin/INRS 2011; Smith et al. 2016). The sandstones are rich in quartz, feldspar, micas, sericite, and chlorite. Opaque minerals such as magnetite and pyrite are also observed in the Huni sandstones and Banket Series (Brako et al. 2020). There are small pockets of the Mesozoic rocks scattered in the area and comprise mafic dyke and dolerite (SNC-Lavalin/INRS 2011).

\section{Hydrogeology}

Hydrogeologically, the Bosome Freho District and Bekwai Municipal belong to the Birimian Province and the Crystalline Basement Granitoids Complex Province (DapaahSiakwan and Gyau-Boakye 2000). The Birimian Province consists of aquifers of the metasediments and metavolcanics of the Birimian Supergroup as well as the Tarkwaian group, while the Crystalline Basement Granitoids Complex is made up of granitoids aquifers. The primary intergranular porosities and permeabilities of the aquifers in the region are typically low. However, secondary porosity arising from the weathering and the activities of Eburnean Orogeny have increased the pores and high fractures within the aquifers (Dappah-Siakwan and Gyau-Boakye 2000). In combination with the topography, structural entity, and lithology, these factors control groundwater occurrence in the region. Within the Crystalline Basement Granitoids Province, groundwater typically occurs in the saprolite, saprock, and fractured bedrock (Banoeng-Yakubu et al. 2011). The mode of groundwater in the Birimian Province is more defined in the lower part of saprolite and the upper part of the saprock. These two regolith profiles are hydraulically connected with their storage and permeability (Carrier et al. 2008). In terms of weathering, rocks of the Birimian show a higher degree of weathering than the granitoids due to the lower jointing and fracturing contained in the granitoids. This has consequently resulted in lower groundwater yields and shallower groundwater tables in granitic terrains. The presence of quartz veins or pegmatites in Birimian Province has been documented to possess higher quantities of groundwater (Carrier et al., 2008). Evidence of long-term borehole drilling records collated in the region from 1991 to 2011 reveals that the Birimian has an average well yield of 30-60 1/min and a higher drilling success rate $(91 \%)$ than the granitoids aquifer with an average borehole yield of $<301 /$ min (Osei-Nuamah and Appiah-Adjei 2017). The groundwater flow pattern in the study area is mostly from north to south and some extent towards the northeastern part. This is consistent with the structural orientation of the Birimian and associated rocks, in which the rocks are oriented $\mathrm{N}-\mathrm{S}$ to NE-SW direction (Leube et al. 1990). The recharge areas are mostly in the northern parts, whereas the discharge areas are in the south and northeast towards Lake Bosumtwi. The wells are within depths ranging between $27 \mathrm{~m}$ and $74 \mathrm{~m}$. The borehole yields in the study area range between $10 \mathrm{l} / \mathrm{min}$ and $300 \mathrm{l} / \mathrm{min}$ with an average of $49 \mathrm{l} / \mathrm{m}$. The transmissivity value also ranges from $0.43 \mathrm{~m}^{2} /$ day to $69.1 \mathrm{~m}^{2} /$ day with an average value of $13.7 \mathrm{~m}^{2} /$ day. The depth to groundwater levels in the study area also vary from $5 \mathrm{~m}$ to $43 \mathrm{~m}$, with an average of $15.3 \mathrm{~m}$.

\section{Methodology}

Groundwater sampling was carried out between 5 September and 9 October 2016 in accordance with sampling procedures espoused by Barcelona et al. (1985). The Garmin Etrex GPS was used to measure the coordinates of the latitude, longitude, and altitude of each borehole. Sixty-four (64) groundwater samples were collected from boreholes with depths ranging between $27 \mathrm{~m}$ and $74 \mathrm{~m}$. Before sampling, the bottles were cleaned in the laboratory by immersing them in a 5\% nitric acid solution and subsequently washing them with distilled water to remove any contaminants in and around the bottles. The boreholes were purged between 5 and $10 \mathrm{~min}$ to have uniform well-mixed water. Unstable and in-situ parameters such as $\mathrm{pH}$ and electrical conductivity were measured in the field using a Hach Multi-Probe Meter. The alkalinity was also measured in the field using the Hach digital titration kit. Groundwater samples were collected into $250 \mathrm{~mL}$ polyethylene bottles for the analysis of major ions and trace elements.

Major cations such as sodium and potassium were analysed using Flame Emission Photometer (Sherwood model 420) at the Water Research Institute laboratory in Accra. Magnesium and calcium were also analysed using Varian AA240 Fast Sequential Atomic Absorption Spectrometer. 
Chloride, sulphate, phosphate, nitrate, and fluoride were analysed by calorimetry using a UV-visible spectrophotometer (Spectroscan 60 DV model). The Atomic Absorption Spectrophotometer was employed to analyse total iron and manganese. All the analysed data were subjected to international certified standards. The accuracy of the hydrochemical parameters was computed using the charge balance error (CBE) formula, which was reproducible within \pm 10 error limits (Appelo and Postma 2005)

$\mathrm{CBE}=\frac{\sum \text { Cations }-\sum \text { Anions }}{\sum \text { Cations }+\sum \text { Anions }} \times 100 \%$,

where $\sum$ Cations and $\sum$ Anions are the sums of the equivalent concentrations of the cations and anions, respectively, measured in milliequivalents per litre (meq/L).

The results of water chemistry were processed using SPSS analytical software version 26.0. Here, the hierarchical cluster analysis tool was used to partition the chemical parameters into homogenous groups according to their similarities and dissimilarities features (Güler et al. 2002). The chemical data were first subjected to a normality test to determine if the datasets are drawn from a Gaussian distributed population (Loh et al. 2020). The datasets that deviate from this normality test were subsequently standardised using the relation in Eq. 2

$Z=\frac{X-\text { mean }}{\text { Stdev }}$,

where $Z$ is the standardised score or measurement; $X$ is the measured chemical parameter.

The standardised datasets were further used to generate hierarchical cluster analysis of the R-mode and Q-mode dendrograms using the Euclidean distance and Ward's linkage method. These methods were used because of their successful outcomes presented in numerous studies ( $\mathrm{Li}$ et al. 2019; Loh et al. 2020). The R-mode HCA was applied to ascertain the sources of the hydrochemical parameters, whereas the Q-mode HCA was used to classify the spatial relationships of the chemical parameters.

On the other hand, the principal component analysis was also employed to reduce the dimensions of the large datasets into components or factors that would help describe the relationship of the chemical parameters. The Kaizer Criterion was used to determine the required number of factors in the model; usually, they have an eigenvalue of 1 . The varimax rotation method was used to increase the variance of the extracted components.

The PHREEQC geochemical modelling software was used to calculate the saturation indices of the minerals present in the groundwater. The Wilcox diagram was used to evaluate the suitability of the groundwater for irrigation. The water quality index (WQI) was computed for the hydrochemical parameters using the expressions in Eqs. (14) to (17). Finally, the water quality distribution map was spatially interpolated by inverse distance-weighted (IDW) technique using ArcGIS software 10.7.1.

\section{Results and discussion}

\section{General hydrochemistry}

The physicochemical parameters and trace metals of the groundwaters in the study area are statistically summarised in Table 1. The $\mathrm{pH}$ values of the groundwater samples lie within the range of 5.25-7.64 with a mean value of 6.25. This suggests that the $\mathrm{pH}$ of the water is neutral-to-moderately acidic (Hounslow 1995). Electrical conductivity is a qualitative parameter that describes the chemical ions present in natural waters (Marandi et al. 2013). The specific conductance values vary from 43.7 to $770 \mu \mathrm{s} / \mathrm{cm}$, suggesting a dilute to highly mineralised groundwater. The lowest specific conductance values (less than $200 \mu \mathrm{s} / \mathrm{cm}$ ) are primarily found in the western and southern parts of the study area.

Similarly, specific conductance values greater than $500 \mu \mathrm{s} / \mathrm{cm}$ generally show an increasing trend towards the eastern parts close to Lake Bosumtwi. The highly mineralised water originates from the leaching and dissolution of the

Table 1 Summary of the physicochemical parameters in the study area

\begin{tabular}{|c|c|c|c|c|c|}
\hline Parameters & Min & Max & Mean & Std Dev & WHO (2017) \\
\hline $\mathrm{pH}$ & 5,25 & 7.64 & 6.25 & 0.51 & $6.5-8.5$ \\
\hline $\mathrm{EC}(\mu \mathrm{s} / \mathrm{cm})$ & 43.7 & 770 & 249.32 & 164.90 & $500-700$ \\
\hline TDS (mg/L) & 24 & 424 & 137.17 & 90.71 & 1000 \\
\hline $\mathrm{Na}^{+}(\mathrm{mg} / \mathrm{L})$ & 4.6 & 107 & 23.75 & 18.79 & 200 \\
\hline $\mathrm{K}^{+}(\mathrm{mg} / \mathrm{L})$ & 0.6 & 17.4 & 4.07 & 3.04 & 30 \\
\hline $\mathrm{Ca}^{2+}(\mathrm{mg} / \mathrm{L})$ & 0.8 & 72.1 & 19.39 & 15.31 & 200 \\
\hline $\mathrm{Mg}^{2+}(\mathrm{mg} / \mathrm{L})$ & 1 & 48.6 & 10.99 & 9.95 & 150 \\
\hline $\mathrm{Cl}^{-}(\mathrm{mg} / \mathrm{L})$ & 5 & 87.6 & 17.20 & 16.63 & $200-250$ \\
\hline $\mathrm{SO}_{4}{ }^{2-}(\mathrm{mg} / \mathrm{L})$ & 0.001 & 94.9 & 8.47 & 13.71 & 250 \\
\hline $\mathrm{PO}_{4}{ }^{3-}(\mathrm{mgL})$ & 0.116 & 2.16 & 0.59 & 0.41 & 30 \\
\hline $\mathrm{NO}_{2}{ }^{-}(\mathrm{mg} / \mathrm{L})$ & 0.001 & 0.117 & 0.01 & 0.02 & 3 \\
\hline $\mathrm{NO}_{3}{ }^{-}(\mathrm{mg} / \mathrm{L})$ & 0.001 & 22.9 & 3.66 & 4.11 & 50 \\
\hline $\mathrm{F}^{-}(\mathrm{mg} / \mathrm{L})$ & 0.004 & 2.94 & 0.047 & 0.544 & $0.5-1.5$ \\
\hline $\mathrm{HCO}_{3}(\mathrm{mg} / \mathrm{L})$ & 24.4 & 488 & 134.10 & 109.62 & NA \\
\hline $\mathrm{NH}_{4}^{-}(\mathrm{mg} / \mathrm{L})$ & 0.001 & 0.001 & 0.001 & 0.655 & NA \\
\hline $\mathrm{Mn}^{2+}(\mathrm{mg} / \mathrm{L})$ & 0.005 & 0.504 & 0.12 & 0.109 & 0.4 \\
\hline $\mathrm{Fe}(\mathrm{mg} / \mathrm{L})$ & 0.01 & 0.504 & 0.12 & 0.116 & 0.3 \\
\hline $\mathrm{Cu}(\mathrm{mg} / \mathrm{L})$ & 0.015 & 0.196 & 0.0236 & 0.022 & 2 \\
\hline As (mg/L) & 0.001 & 0.006 & 0.00123 & 0.000868 & 0.01 \\
\hline $\mathrm{Pb}(\mathrm{mg} / \mathrm{L})$ & 0.005 & 0.005 & 0.005 & 0.2622 & 0.01 \\
\hline $\mathrm{Zn}(\mathrm{mg} / \mathrm{L})$ & 0.005 & 0.285 & 0.027 & 0.0473 & 3 \\
\hline
\end{tabular}


fractured plutonic rocks, which possibly contain more ionic water, and is hydraulically connected with the Tarkwaian rocks that overlie unconformably on the Birimian formations. The TDS concentrations range from 24 to $424 \mathrm{mg} / \mathrm{L}$ with an average of $137 \mathrm{mg} / \mathrm{L}$, suggesting that the groundwater in the study is relatively young (Freeze and Cherry 1979). The low TDS concentrations correlate with the relatively low specific conductance values in the study area, mainly due to the shorter residence time of the groundwater. All the major ions and trace metals are within the WHO acceptable limits for drinking water except for one borehole with fluoride concentrations of $2.94 \mathrm{mg} / \mathrm{L}$. The elevated fluoride concentration can intuitively be described as sampling or laboratory error. This is because all the boreholes have fluoride concentrations less than the WHO acceptable limits for fluoride in drinking water $(1.5 \mathrm{mg} / \mathrm{L})$. In addition, one borehole sample has a total iron and manganese concentration above the WHO background value of $0.3 \mathrm{mg} / \mathrm{L}$ and $0.4 \mathrm{mg} / \mathrm{L}$, respectively.

\section{Major ions' chemistry and correlations}

The major groundwater quality parameters were evaluated by their relationships using Pearson's correlation coefficient $(r)$. The correlation coefficient $(r)$ has an interval of -1 and 1 , and is usually tested at a significant level of $P<0.05$ (Table 2). Generally, strong and weak correlations values $(r)$ are used to infer the relationships of the chemical parameters. These values lie in the range between $r>0.7$ and $r<0.5$, respectively, while moderate correlations $(r)$ values lie between 0.5 and 0.7 . In the study area, the orders of dominance of the cations are $\mathrm{Na}^{+}>\mathrm{Ca}^{2+}>\mathrm{Mg}^{2+}>\mathrm{K}^{+}$and for the anions are $\mathrm{HCO}_{3}{ }^{-},>\mathrm{Cl}^{-}>, \mathrm{SO}_{4}{ }^{2-}>\mathrm{NO}_{3}^{-}$. For the cations, sodium appears copiously in most of the groundwater wells due to the weathering of the silicate minerals such as albite and plagioclase found in the host plutonic rocks. Sodium correlates strongly with $\mathrm{SO}_{4}{ }^{2-}(r=0.77)$, TDS $(r=0.77)$ and EC $(r=0.77)$. The moderate correlation between $\mathrm{Na}^{+}$and $\mathrm{HCO}_{3}{ }^{-}(r=0.67)$ suggests bicarbonate enriched groundwater that is usually produced along with silicate weathering (Appelo and Postma 2005). The correlation between $\mathrm{Na}^{+}$ and $\mathrm{Ca}^{2+}(r=0.53)$ suggests cation-exchange reactions in the aquifer where there is a slight enrichment of $\mathrm{Na}^{+}$(mean of $23.75 \mathrm{mg} / \mathrm{L}$ ) relative to $\mathrm{Ca}^{2+}$ (mean of $19.39 \mathrm{mg} / \mathrm{L}$ ) (Clark 2015). A noted weak correlation between $\mathrm{Na}+$ and $\mathrm{Cl}^{-}(r=0.36)$ suggests low salinity groundwaters or silicate mineral dissolution other than halite as its origin.

Calcium appears to be the second dominant cation and correlates strongly with pH $(r=0.71)$, EC $(r=0.87)$, TDS $(r=0.87), \mathrm{Mg}^{2+}(r=0.71)$, and $\mathrm{HCO}_{3}{ }^{-}(r=0.87)$. Significant amounts of calcium in groundwater originate from carbonate weathering and dissolution, such as calcite and ankerite. According to Mumin and Fleet (1994), these minerals are ubiquitous in variable amounts in the Birimian and Tarkwaian sedimentary rocks of the Ashanti Belt of Ghana. Linings of carbonate minerals even found in crystalline terrains tend to dissolve more rapidly and dominate groundwater geochemistry than silicate rocks (Leybourne and Goodfellow (2010). This explains the significant correlation of calcium and magnesium, and is consistent with the results of the saturation indices. Magnesium is the third dominant cation, and its occurrence in groundwater can be explained by the weathering and dissolution of biotite and chlorite minerals in the granite and Birimian rocks of the area (Clark 2015). It can be added that the dissolution of carbonate minerals such as dolomite $\left(\mathrm{CaMg}\left(\mathrm{CO}_{3}\right)_{2}\right.$ and magnesite $\left(\mathrm{MgCO}_{3}\right)$

Table 2 Correlation matrix table of the chemical parameters in the study area

\begin{tabular}{|c|c|c|c|c|c|c|c|c|c|c|c|c|c|c|}
\hline & $\mathrm{pH}$ & $\mathrm{EC}$ & TDS & $\mathrm{Na}^{+}$ & $\mathrm{K}^{+}$ & $\mathrm{Ca}^{2+}$ & $\mathrm{Mg}^{2+}$ & $\mathrm{Cl}^{-}$ & $\mathrm{SO}_{4}^{2-}$ & $\mathrm{PO}_{4}^{3-}$ & $\mathrm{Mn}^{2+}$ & $\mathrm{NO}_{3}^{-}$ & $\mathrm{F}^{-}$ & $\mathrm{HCO}_{3}$ \\
\hline $\mathrm{pH}$ & 1.00 & & & & & & & & & & & & & \\
\hline $\mathrm{EC}$ & 0.68 & 1.00 & & & & & & & & & & & & \\
\hline TDS & 0.68 & 1.00 & 1.00 & & & & & & & & & & & \\
\hline $\mathrm{Na}^{+}$ & 0.41 & 0.77 & 0.77 & 1.00 & & & & & & & & & & \\
\hline $\mathrm{K}^{+}$ & -0.23 & 0.06 & 0.06 & 0.09 & 1.00 & & & & & & & & & \\
\hline $\mathrm{Ca}^{2+}$ & 0.71 & 0.87 & 0.87 & 0.53 & -0.01 & 1.00 & & & & & & & & \\
\hline $\mathrm{Mg}^{2+}$ & 0.75 & 0.89 & 0.89 & 0.58 & -0.11 & 0.71 & 1.00 & & & & & & & \\
\hline $\mathrm{Cl}^{-}$ & -0.11 & 0.36 & 0.36 & 0.31 & 0.40 & 0.24 & 0.08 & 1.00 & & & & & & \\
\hline $\mathrm{SO}_{4}^{2-}$ & 0.11 & 0.47 & 0.47 & 0.77 & 0.13 & 0.18 & 0.38 & 0.07 & 1.00 & & & & & \\
\hline $\mathrm{PO}_{4}^{3-}$ & 0.06 & -0.04 & -0.04 & 0.07 & 0.02 & -0.01 & -0.07 & -0.02 & -0.12 & 1.00 & & & & \\
\hline $\mathrm{Mn}^{2+}$ & 0.23 & 0.29 & 0.29 & -0.07 & 0.03 & 0.39 & 0.25 & 0.09 & -0.07 & -0.19 & 1.00 & & & \\
\hline $\mathrm{NO}_{3}^{-}$ & -0.38 & -0.27 & -0.27 & -0.23 & 0.117 & -0.24 & -0.36 & 0.10 & -0.11 & -0.3 & 0.21 & 1.00 & & \\
\hline $\mathrm{F}^{-}$ & 0.27 & 0.40 & 0.40 & 0.45 & -0.08 & 0.44 & 0.21 & 0.08 & 0.05 & 0.21 & -0.13 & -0.1 & 1.00 & \\
\hline $\mathrm{HCO}_{3}^{-}$ & 0.80 & 0.91 & 0.91 & 0.67 & -0.1 & 0.87 & 0.91 & -0.01 & 0.41 & 0.01 & 0.25 & -0.39 & 0.41 & 1.00 \\
\hline
\end{tabular}

Bolded values indicate strong correlation $\mathrm{r}>0.7$; moderate correlation $0.5<r<0.7$ 
in the underlying Birimian rocks may contribute to $\mathrm{Mg}^{2+}$ enrichment in the groundwater (Mumin and Fleet 1994; Loh et al. 2016).

Carbonate weathering usually takes place in open and closed systems. Under the open system, carbonic acid concentrations are consumed during carbonate weathering/ dissolution. They are replenished and maintained constant by soil $\mathrm{CO}_{2}$ from the open soil air under fixed $\mathrm{CO}_{2}$ partial pressure. Further weathering will create calcite saturation equilibrium with no further dissolution. This, thus, causes higher solute concentrations with increasing groundwater residence time in the unsaturated zone (Clark 2015).

On the contrary, there is a limitation of $\mathrm{CO}_{2}$ during groundwater recharge in the unsaturated zone under a closed system. This usually occurs in recharge areas, where water runs quickly in the saturated zone. Here, there is minimal weathering and less groundwater-rock interaction. This evolves the $\mathrm{CO}_{2}$ partial pressure to low values, increases the $\mathrm{pH}$ of the groundwater, and eventually leads to the non-saturation of the calcite mineral (Clark 2015). Potassium is the least dominant cation in the area and exhibits low concentrations in the groundwater wells. Potassium in groundwater is attributed to feldspar mineral weathering and synthetic fertilisers from agricultural activities. However, potassium concentrations in groundwater are very low due to the high resistance of potassium feldspar and biotite minerals to weathering (Appelo and Postma 2005). Hölting and Coldewey (2019) also postulated that potassium ions are usually adsorbed and bound to the aquifer, thus reducing potassium concentration in groundwater. In the study area, potassium correlates weakly with all the groundwater parameters. This suggests the absence of low potassium-bearing minerals or the little use of potassium fertiliser in the area.

Bicarbonate is the main conspicuous anion occurring in most groundwater wells. Bicarbonate correlates strongly with TDS $(r=0.91)$, EC $(r=0.91)$, and $\mathrm{Mg}^{2+}(r=0.91)$, and moderately with $\mathrm{Na}^{+}(r=0.67)$. The dominance of bicarbonate in the groundwaters can be explained as calcite mineral dissolution. Natural atmospheric $\mathrm{CO}_{2}$ in contact with water produces weak carbonic acid $\left(\mathrm{H}_{2} \mathrm{CO}_{3}\right)$. The weak carbonic acid dissociates to give $\mathrm{HCO}_{3}{ }^{-}$and $\mathrm{H}^{+}$. During calcite mineral dissolution, there is a gradual change of $\mathrm{CO}_{3}{ }^{2-}$ to $\mathrm{HCO}_{3}{ }^{-}$, and this explains the strong positive correlation between $\mathrm{Ca}^{2+}$ and $\mathrm{HCO}_{3}^{-}(r=0.87)$. Another source of bicarbonate in groundwaters is silicate mineral weathering, which is accompanied by the release of bicarbonate ions in the solution (Appelo and Postma 2005). Nitrate and chloride correlate weakly with all the groundwater parameters, indicating that anthropogenic activities do not have a dominant effect on the groundwater chemistry in the study area.

Sulphate occurs in groundwater from natural and anthropogenic sources. Natural atmospheric deposition of sulphate can increase sulphate concentrations in groundwater.
Anthropogenic activities such as fertiliser application, burning of fossil fuels, or ore smelting can increase sulphate concentrations in the near-surface groundwater (Sharma and Kumar 2020). Sulphide-bearing minerals such as pyrite and arsenopyrite are common predominant minerals associated with gold mineralisation in Ghana (Brako et al. 2020). The weathering of pyrite minerals in contact with oxygen and water, catalysed by microbes and bacteria, can form acid mine drainage (Nordstrom 2011). This, when discharges into streams and near-surface groundwater, can result in elevated sulphate concentration and acidic groundwater. In the study area, sulphate concentration is very low and correlates weakly with all the groundwater parameters except fluoride with moderate correlation $(r=0.5)$ and $\mathrm{Na}^{+}(r=0.77)$. This possibly indicates relatively minor impacts of these activities towards the enrichment of sulphate in the groundwater. The anion composition of the groundwater is along its flow path, which $\mathrm{HCO}_{3}{ }^{-}$dominates and the low concentrations of $\mathrm{SO}_{4}{ }^{2-}$ and $\mathrm{Cl}^{-}$indicates recharge zone. This is because discharge areas of groundwater flow evolution usually have high $\mathrm{SO}_{4}{ }^{2-}$ and $\mathrm{Cl}^{-}$concentrations (Ophori and Toth 1989).

\section{Spatial groundwater types using multivariate statistics}

A multivariate statistical tool is mostly applied in groundwater geochemistry to assembly water samples into homogenous groups based on their similarity and dissimilarity characteristics (Güler et al. 2002). Here, hierarchical cluster analysis (HCA) was applied on 64 groundwater samples (Q-mode HCA) and 13 variables (R-mode HCA) to establish the various geochemical groupings. The R-mode HCA (Fig. 4a) describes the relationship between the hydrochemical parameters, and with this, three clusters were generated. A phenon line was connected at a distance of 15 to prohibit the generation of greater or fewer clusters for meaningful water chemistry data interpretation.

Cluster 1 consists of EC, TDS, $\mathrm{Mg}^{2+}, \mathrm{HCO}_{3}{ }^{-}, \mathrm{Ca}^{2+}$, and $\mathrm{pH}$, suggesting carbonate mineral dissolution that releases significant bicarbonate ions in the water. This cluster particularly $\left(\mathrm{Ca}^{2+}, \mathrm{Mg}^{2+}\right.$, and $\left.\mathrm{HCO}_{3}^{-}\right)$also suggests that groundwater is indicative of recharging waters undergoing an initial phase of hydrogeochemical evolution (Ophori and Toth 1989). $\mathrm{Na}^{+}, \mathrm{SO}_{4}{ }^{2-}$, and $\mathrm{F}^{-}$characterise the second cluster ${ }^{-}$and has a longer linkage distance than cluster 1. The presence of $\mathrm{Na}^{+}$may come from the dissolution of silicate mineral albite in the underlying granitic rocks of the area. This cluster also represents the cation-exchange process, in which $\mathrm{Na}^{+}$displaces $\mathrm{Ca}^{2+}$ in the water. Cluster 3 consists of $\mathrm{Mn}^{2+}, \mathrm{K}^{+}, \mathrm{Cl}^{-}$, and $\mathrm{NO}_{3}{ }^{-}$, and generally, these parameters occur in elevated concentrations in groundwater due to anthropogenic activities such as the seepage of domestic waste and the use of chemical fertilisers (Loh et al. 
Fig. 4 a The R- mode HCA

of the chemical parameters in the study area. b The Q- mode

HCA of the spatial groundwater associations in the study area
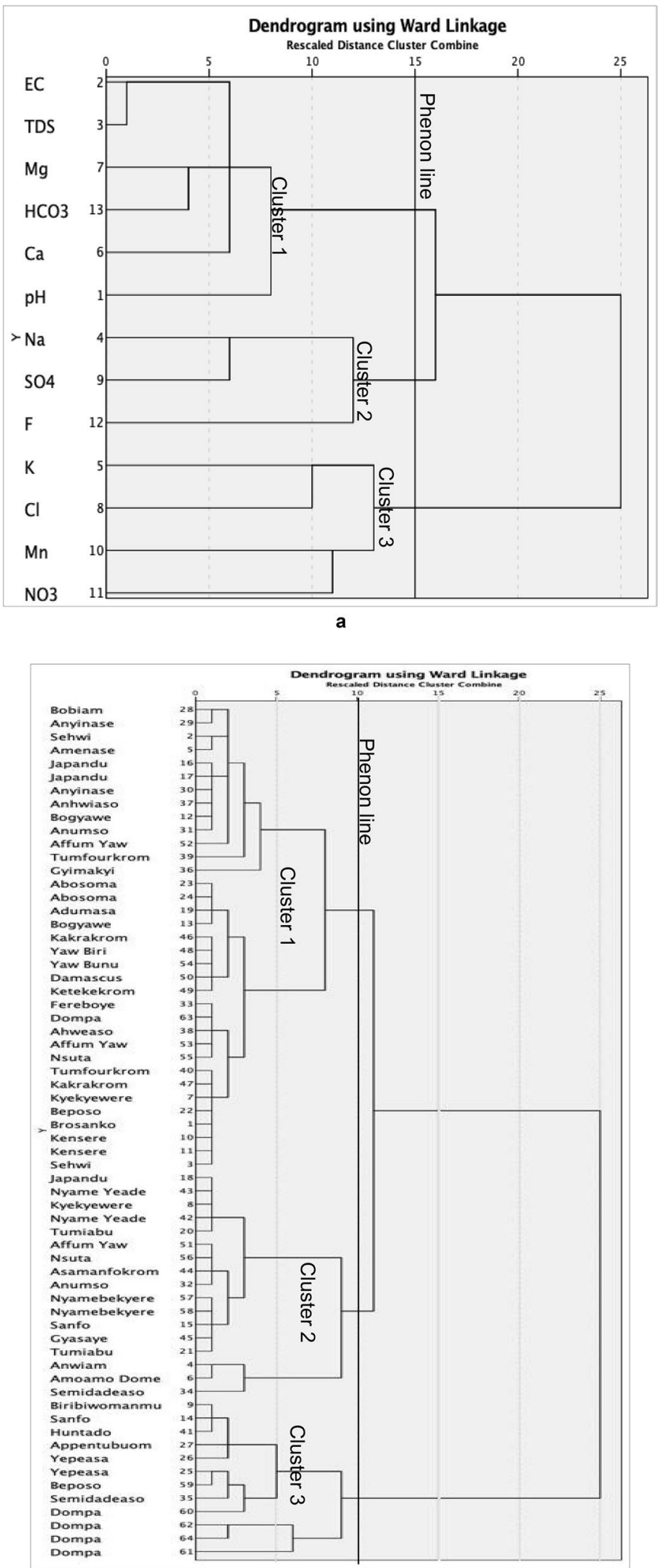
2020). The longer linkage distance of cluster 3 relative to the other clusters indicates that these parameters are of geogenic origin other than anthropogenic activities. This assertion is supported by the non-significant correlation among these parameters in the correlation matrix (Table 2).

Figure 4b shows three spatial groundwater clusters generated by the Q-mode HCA. Cluster 1 is characterised by $\mathrm{Ca}-\mathrm{Mg}-\mathrm{HCO}_{3}$ water types with low average TDS and EC concentrations of $77 \mathrm{mg} / \mathrm{L}$ and $140 \mathrm{~s} \mu / \mathrm{cm}$, respectively. From Fig. 5, it is evident that the majority of cluster 1 samples are found in high topographic areas such as Beposo, Bobian, Japandu, Nsuta, and Anyinase, ranging between 120 and $340 \mathrm{~m}$ above sea level. This cluster is distinctive of a recharge area, where low ionic concentrations from precipitations are quite the same as the early stages of recharging waters during groundwater evolution. The second cluster of the Q-mode $\mathrm{HCA}$ is characterised by $\mathrm{Ca}-\mathrm{Na}-\mathrm{Mg}-\mathrm{HCO}_{3}$ or $\mathrm{Na}-\mathrm{Ca}-\mathrm{Mg}-\mathrm{HCO}_{3}$ water types with average TDS and EC of $159 \mathrm{mg} / \mathrm{L}$ and $279 \mu \mathrm{S} / \mathrm{cm}$, respectively. This cluster can be described as a transition zone from recharge areas to discharge areas. The third cluster comprises $\mathrm{Na}-\mathrm{Ca}-\mathrm{Mg}-\mathrm{HCO}_{3}$ or $\mathrm{Na}-\mathrm{Ca}-\mathrm{Mg}-\mathrm{HCO}_{3}-\mathrm{Cl}$ water type with high TDS values of $290 \mathrm{mg} / \mathrm{L}$ and EC values of $526 \mu \mathrm{S} / \mathrm{cm}$. This cluster occurs in low topographical elevation areas such as Dompa, Huntado, and Sanfo, ranging from 97 to $170 \mathrm{~m}$ above sea level. Cluster 3 represents discharge area, which corresponds to the assertion that lowland areas are discharge areas in the groundwater evolution regime (Freeze and Cherry 1979). During groundwater quality evolution, the major ions, EC, and TDS, progressively increase from recharge areas towards discharge areas with prolonged residence time. This pattern is observed in Fig. 5, where groundwater containing low ionic content flows from the northern and middle parts (recharge zone) to the southern part (discharge zone) with high ionic content. Groundwater discharge also occurs in the northeastern part of Lake Bosumtwi and its surrounding areas.

Furthermore, the major ions increase with increasing depth as groundwater travels from recharge to discharge areas, as seen in Fig. 5. Cluster 1 samples (recharge zone) prevail in a groundwater depth ranging between 27 and $60 \mathrm{~m}$, while cluster 3 samples (discharge zone) are mostly found in borehole depths between 58 and $74 \mathrm{~m}$. This pattern shows a geogenic process in which there is a gradual buildup of major ions with increasing ionic concentration and well depth towards discharge areas. The relationship between

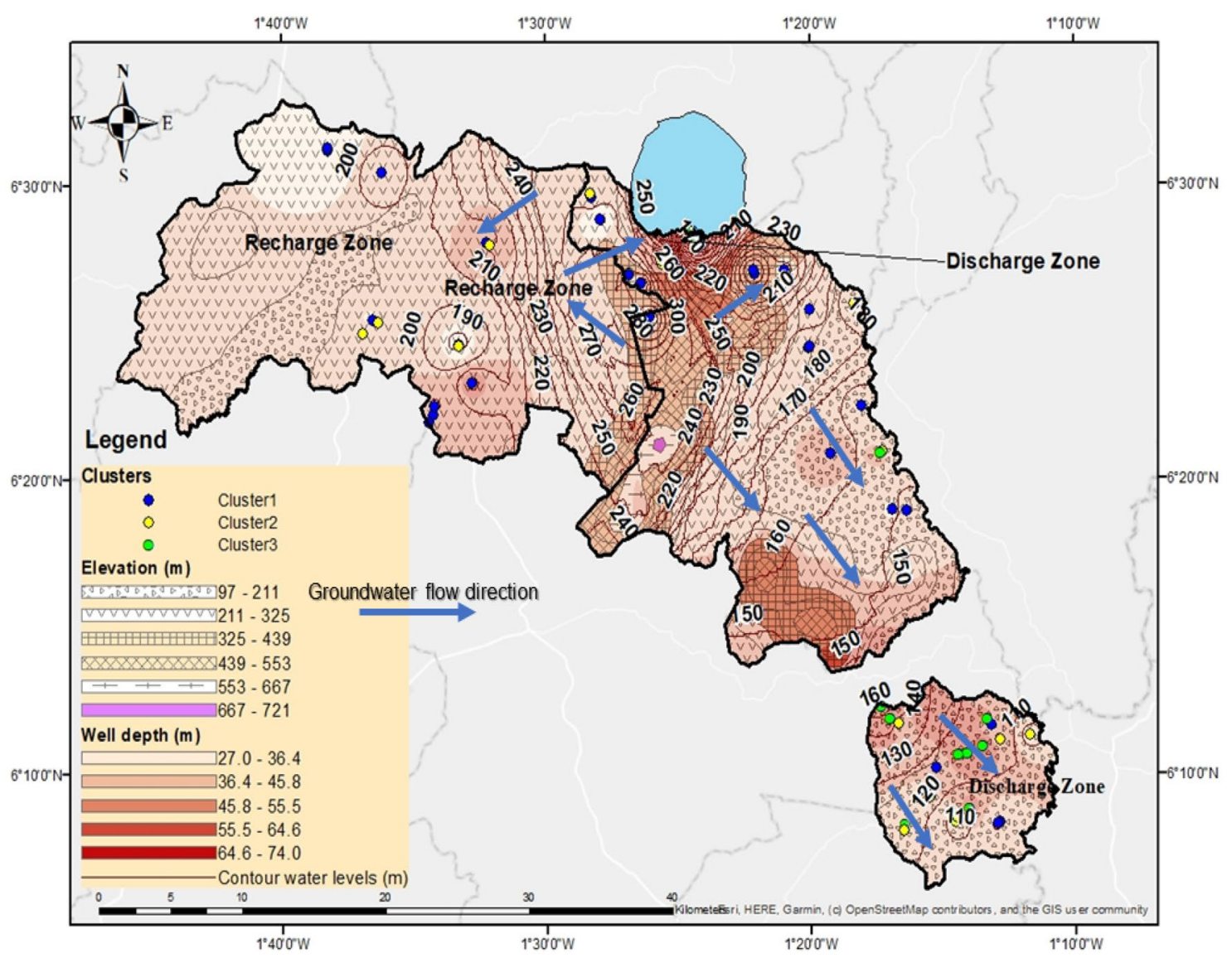

Fig. 5 Spatial distribution of the clusters generated from the Q-mode HCA showing discharge, recharge zones, and groundwater flow direction 
geochemical process and well depth is broadly described by Hagmaier (1971) and Bartos et al. (2002). According to their classification, shallow groundwaters are often dominated by $\mathrm{Ca}^{2+}, \mathrm{Na}^{2+}, \mathrm{HCO}_{3}{ }^{-}$, and $\mathrm{SO}_{4}{ }^{2-}$ water types in recharge areas and give way to $\mathrm{Na}^{2+}, \mathrm{Ca}^{2+}, \mathrm{HCO}_{3}{ }^{-}$, and $\mathrm{SO}_{4}{ }^{2}$ water types in discharge areas with increasing depth. This pattern is observed in the study area.

\section{Hydrogeochemical facies}

The Q-mode HCA was used to unveil the hydrogeochemical facies of groundwater in the study area. The major ions and groundwater types are represented on the trilinear Piper diagram. From the Piper diagram (Fig. 6), all the three clusters are grouped in the no-dominant water type (mixed zone) of the cation's triangle. A small portion of the cluster 1 samples are within the $\mathrm{Na}+\mathrm{K}$ zone. The anions triangle is mainly dominated by the bicarbonate water type of nearly all three clusters. Few samples from cluster 2 fall in the chloride water type. Generally, three groundwater water types can be categorised in the trilinear Piper diagram by their chemical compositions.

The first type is $\mathrm{Ca}-\mathrm{Mg}-\mathrm{HCO}_{3}$ water, which suggests a freshwater type of the Birimian aquifer system recharged during the initial stage of hydrochemical evolution. This also shows a dominance of alkaline earth metals associated with weak acidic anions $\left(\mathrm{HCO}_{3}{ }^{-}\right)$over the alkali metals $(\mathrm{Na}+\mathrm{K})$ and strong acidic anions $\left(\mathrm{SO}_{4}+\mathrm{Cl}\right)($ Adimalla 2020b; Tran et al. 2020). The second type is $\mathrm{Ca}-\mathrm{Na}-\mathrm{HCO}_{3}$ or $\mathrm{Na}-\mathrm{Ca}-\mathrm{HCO}_{3}$ mixed water and different geochemical processes such as cation-exchange reaction, silicate, and carbonate mineral dissolution. The third type is $\mathrm{Na}+\mathrm{K}-\mathrm{Cl}+\mathrm{SO}_{4}$ water. $\mathrm{Na}-\mathrm{Cl}$ water types are often interpreted as saline groundwater due to seawater intrusion. However, the area is several kilometres away from the sea. The low TDS concentrations $(<450 \mathrm{mg} / \mathrm{l})$ can be explained as the influence of local meteoric water on the groundwater recharge of the study area (Yidana et al. 2010).

\section{Factor analysis}

Principal component analysis using varimax rotation and Kaiser normalisation was applied on 64 groundwater samples and 13 chemical parameters, of which three principal components were generated, accounting for $80 \%$ of the total variance (Tables 3, 4). PCA1 accounts for $47 \%$ of the total variance in the three factors and exhibits strong positive loadings for $\mathrm{pH}$, TDS, $\mathrm{EC}, \mathrm{Na}^{+}, \mathrm{Ca}^{2+}, \mathrm{Mg}^{2+}, \mathrm{Mn}^{2+}$, and $\mathrm{HCO}_{3}{ }^{-}$(Fig. 7). This factor implies different sets of geochemical processes occurring in the aquifer. For instance, the high positive loadings of $\mathrm{Ca}^{2+}, \mathrm{HCO}_{3}{ }^{-}$, and $\mathrm{Mg}^{2}$ of PCA1 suggest carbonate and silicate mineral weathering reflecting the minerals in the underlying geology of the area. Therefore, carbonate and silicate mineral dissolution can be described as the essential geochemical processes controlling groundwater chemistry in the area.

In contrast, there are low and negative loadings of $\mathrm{K}^{+}$, $\mathrm{NO}_{3}{ }^{-}, \mathrm{SO}_{4}{ }^{2-}$, and $\mathrm{F}^{-}$in PCA1. This suggests that anthropogenic activities are not the principal factors that control groundwater chemistry in the study area. PCA2 loads strongly with $\mathrm{Na}^{+}, \mathrm{SO}_{4}{ }^{2-}$, and low loadings for the other parameters, and accounts for $20 \%$ of the total variance. This also highlights similar findings obtained in the correlation matrix between $\mathrm{Na}^{+}$and $\mathrm{SO}_{4}{ }^{2-}$. The dominance of $\mathrm{Na}^{+}$over the other cations in this factor explains the cation-exchange process, in which $\mathrm{Na}^{+}$displaces $\mathrm{Ca}^{2+}$ and $\mathrm{Mg}^{2+}$ in solution. The high positive loading of $\mathrm{Na}^{+}$also implies the weathering of silicate mineral albite, which is found in the granitic
Fig. 6 Piper diagram showing the groundwater types in the study area

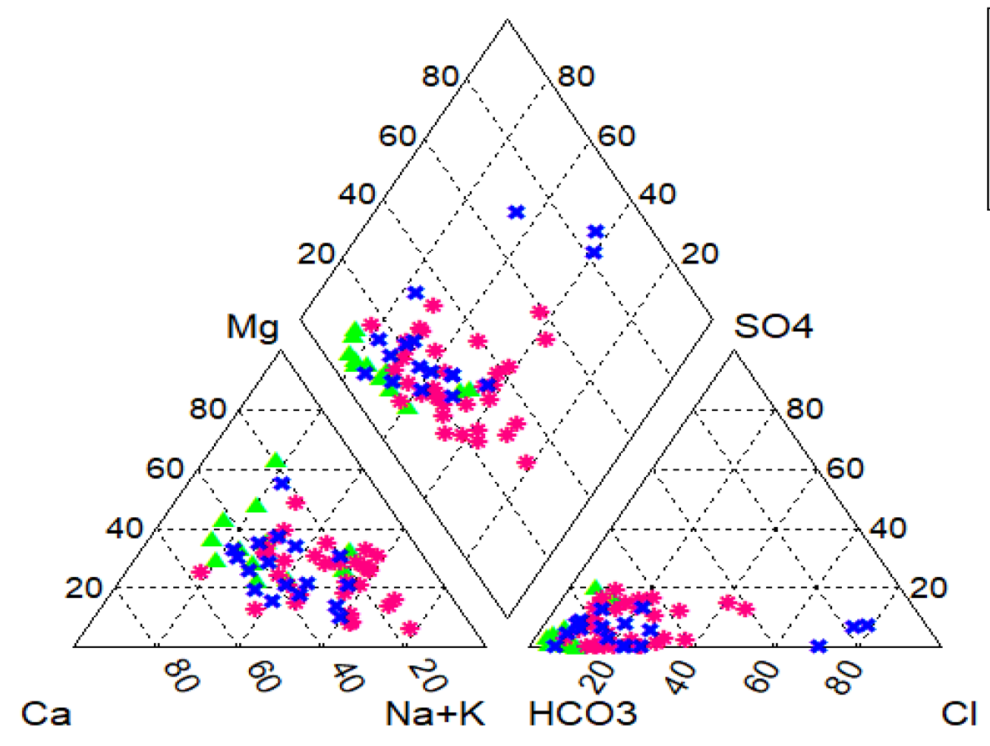

Legend

Cluster 3

* Cluster1 
Table 3 Cumulative variance of the PCA

\begin{tabular}{|c|c|c|c|c|c|c|c|c|c|}
\hline \multirow[t]{2}{*}{ Component } & \multicolumn{3}{|c|}{ Initial Eigenvalues } & \multicolumn{3}{|c|}{ Extraction sums of squared loadings } & \multicolumn{3}{|c|}{ Rotation sums of squared loadings } \\
\hline & Total & $\%$ of Variance & Cumulative $\%$ & Total & $\%$ of Variance & Cumulative \% & Total & $\%$ of Variance & Cumulative $\%$ \\
\hline 1 & 6.304 & 53.490 & 53.490 & 6.304 & 53.490 & 53.490 & 5.681 & 46.701 & 43.701 \\
\hline 2 & 2.527 & 15.717 & 69.207 & 2.527 & 15.717 & 69.207 & 2.893 & 19.660 & 66.361 \\
\hline 3 & 1.783 & 11.407 & 80.614 & 1.783 & 11.407 & 80.614 & 2.040 & 14.253 & 80.614 \\
\hline 4 & 0.985 & 6.041 & 86.665 & & & & & & \\
\hline 5 & 0.887 & 4.422 & 91.007 & & & & & & \\
\hline 6 & 0.593 & 3.562 & 94.639 & & & & & & \\
\hline 7 & 0.406 & 2.123 & 96.762 & & & & & & \\
\hline 8 & 0.228 & 1.550 & 98.312 & & & & & & \\
\hline 9 & 0.184 & 1.115 & 99.427 & & & & & & \\
\hline 10 & 0.068 & 0.524 & 99.849 & & & & & & \\
\hline 11 & 0.011 & 0.087 & 99.936 & & & & & & \\
\hline 12 & 0.008 & 0.064 & 100.000 & & & & & & \\
\hline 13 & $1.83 \mathrm{E} 03$ & $1.41 \mathrm{E}-02$ & 100.000 & & & & & & \\
\hline
\end{tabular}

Table 4 Factor loadings of the chemical parameters

\begin{tabular}{lrrr}
\hline Parameters & \multicolumn{2}{r}{2} & \multicolumn{1}{l}{3} \\
\hline $\mathrm{pH}$ & 0.820 & 0.007 & -0.348 \\
$\mathrm{TDS}$ & 0.920 & 0.297 & 0.175 \\
$\mathrm{EC}$ & 0.921 & 0.297 & 0.175 \\
$\mathrm{Na}^{+}$ & 0.550 & 0.680 & 0.193 \\
$\mathrm{~K}^{+}$ & -0.093 & 0.193 & 0.712 \\
$\mathrm{Ca}^{2+}$ & 0.920 & -0.044 & 0.094 \\
$\mathrm{Mg}^{2+}$ & 0.879 & 0.277 & -0.141 \\
$\mathrm{Cl}^{-}$ & 0.173 & 0.047 & 0.811 \\
$\mathrm{SO}_{4}{ }^{2-}$ & 0.231 & 0.890 & 0.111 \\
$\mathrm{Mn}^{-}$ & 0.512 & -0.412 & 0.225 \\
$\mathrm{NO}_{3}{ }^{-}$ & -0.254 & -0.319 & 0.472 \\
$\mathrm{~F}^{-}$ & 0.343 & -0.072 & 0.051 \\
$\mathrm{HCO}_{3}^{-}$ & 0.926 & 0.256 & -0.162 \\
\hline
\end{tabular}

rocks of the area. PCA3 explains $14 \%$ of the total variance with strong positive loadings of $\mathrm{K}^{+}$and $\mathrm{Cl}^{-}$indicating the leaching of agricultural fertilisers and domestic waste in the groundwaters (Rusydi 2018). However, it must be noted that the low $\mathrm{K}^{+}$and $\mathrm{Cl}^{-}$concentrations in the groundwater samples imply that the application of potassium chloride fertilisers in the area may not contribute to the enrichment of these ions in the groundwater.

\section{Saturation index (SI)}

The solubility of aquifer minerals in a particular geochemical environment can be examined to determine the maximal concentrations in solution (Appelo and Postma 2005).

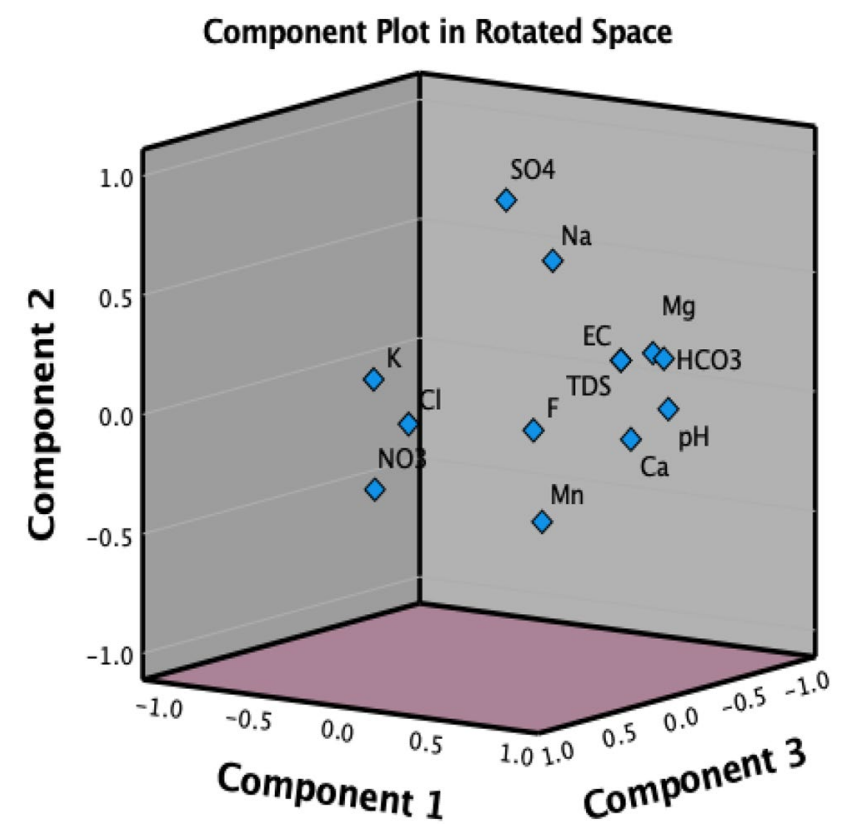

Fig. 7 A rotated diagram showing the three components extracted

Under equilibrium conditions, minerals such as carbonate and halite dissolve faster in water. Conversely, some minerals may take a longer time to dissolve in water until it becomes supersaturated and the minerals precipitate out from the solution. For example, quartz $\left(\mathrm{SiO}_{2}\right)$ precipitation and silicate minerals dissolve slowly, and can be modelled further using kinetic reactions (Appelo and Postma 2005). Hence, mineral species in an aquifer can be investigated by calculating the saturation index expressed as 
$\mathrm{SI}=\log \left(\frac{\mathrm{IAP}}{K_{\mathrm{S}}(\mathrm{T})}\right)$,

where $K_{\mathrm{s}}(\mathrm{T})$ is the solubility constant for temperature dependence of the mineral; IAP is the ion activity product. $\mathrm{Si}=0$ mineral is in equilibrium with the solution. $\mathrm{Si}<0$ mineral is undersaturated (may reflect mineral dissolution in the water). $\mathrm{Si}>0$ mineral is supersaturated (may reflect mineral precipitation in the water).

The saturation indices of the 64 groundwater samples were assessed using geochemical modelling software PHREEQC (Parkhurst and Appelo 2013).

From Fig. 8, it is apparent that the groundwaters in the study area are undersaturated with respect to halite, fluorite, and gypsum, indicating the dissolution of these minerals if present in the groundwater. Again, nearly all the groundwaters are undersaturated with respect to calcite and dolomite, suggesting the dissolution of carbonates minerals. Three and six groundwater samples are supersaturated with respect to calcite and dolomite, respectively, and have neutral $\mathrm{pH}$ values ranging between 7.2 and 7.4. This suggests that the carbonate minerals are forming and may contain sufficient minerals needed to attain equilibrium (Appelo and Postma 2005; Clark 2015). The dissolution of carbonate minerals involving calcite and dolomite is often aided by $\mathrm{CO}_{2}$ derived from organic matter degradation and respiration, releasing significant amounts of bicarbonate ions in the solution. The mechanism is explained below

$\mathrm{CO}_{2}+\mathrm{H}_{2} \mathrm{O}+\mathrm{CaCO}_{3} \rightarrow \mathrm{Ca}^{2+}+2 \mathrm{HCO}_{3}^{-}$calcite dissolution

$2 \mathrm{CO}_{2}+2 \mathrm{H}_{2} \mathrm{O}+\mathrm{CaMg}\left(\mathrm{CO}_{3}\right)_{2} \rightarrow \mathrm{Ca}^{2+}+\mathrm{Mg}^{2+}+4 \mathrm{HCO}_{3}^{-}$dolomite dissolution.

\section{Ionic ratios and sources of major ions in groundwater}

The genesis of groundwater and the major drivers controlling water chemistry can be explained using the relationships of different major ions (ionic ratios). For groundwater salinity, its origin may be derived from the halite dissolution and seawater intrusion, or can be invoked from silicate weathering (Hounslow 1995). For the plot of $\mathrm{Na}^{+}$ versus $\mathrm{Cl}^{-}$(Fig. 10a), more than half of the groundwater samples are below the 1:1 line, which indicates that the groundwater salinity in the study area is mainly from cation-exchange processes or silicate weathering typically
Fig. 8 Saturation indices of the mineral spices

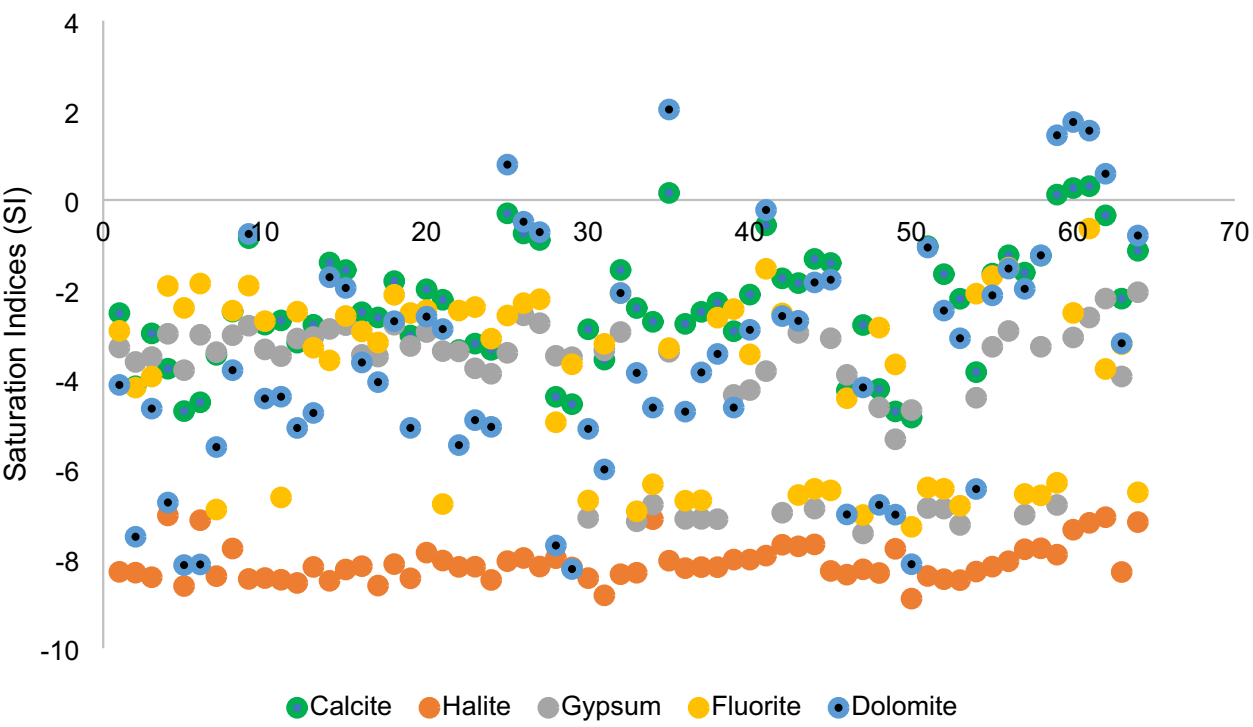


Fig. 9 a Gibbs diagram of the cations TDS versus $\mathrm{Na}^{-} /$ $\mathrm{Na}^{-}+\mathrm{Cl}^{-}$and $\mathbf{b}$ the Gibbs anions diagram TDS versus $\mathrm{Cl}^{-} /$ $\left(\mathrm{Cl}^{-}+\mathrm{HCO}_{3}^{-}\right)$
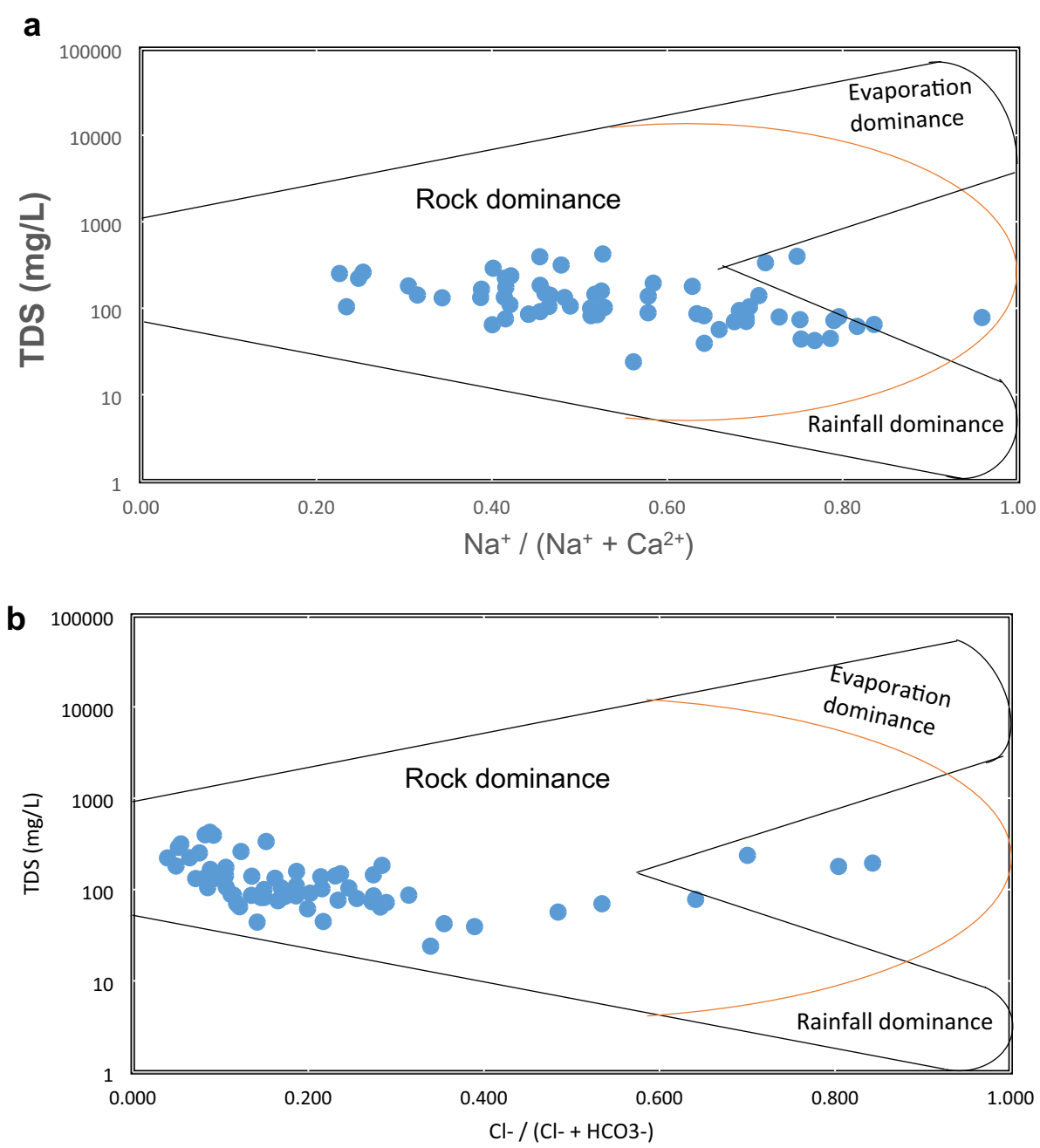

of albite mineral; this releases significant amounts of $\mathrm{Na}^{+}$ and $\mathrm{HCO}_{3}{ }^{-}$into the groundwater illustrated in the relation below. On the other hand, some of the groundwater samples fall above the 1:1 line. According to Meybeck (1987), this results from reverse ion exchange between sodium and chloride in which there is an enrichment of chloride ions

$$
\begin{aligned}
& 2 \mathrm{NaAlSi}_{3} \mathrm{O}_{8}(\text { albite })+2 \mathrm{H}_{2} \mathrm{CO}_{3}+9 \mathrm{H}_{2} \mathrm{O} \rightleftharpoons 2 \mathrm{Na}^{+} \\
& +4 \mathrm{H}_{4} \mathrm{SiO}_{4}^{+} \mathrm{Al}_{2} \mathrm{SiO}_{5}(\mathrm{OH})_{4}(\text { Kaolinite }) \\
& \left.+2 \mathrm{HCO}_{3}^{-} \text {(bicarbonate }\right) .
\end{aligned}
$$

The plot of $\mathrm{HCO}_{3}{ }^{-}$versus $\mathrm{Ca}^{2+}+\mathrm{Mg}^{2+}$ (Fig. 10b) was used further to unveil more information about carbonate and silicate mineral dissolution in the aquifer. If the trends of groundwater samples fall along the 1.1 line, they indicate that carbonate mineral dissolution prevails in an aquifer. If the samples do not fall on the line, it could be the alteration of silicates. The plot shows that the majority of samples are along and above the 1:1 line, which suggests the dissolution of carbonate minerals in the area. (Zaidi et al. 2015).
To further validate the carbonate and silicate mineral dissolutions into the groundwaters in the study area, the plot of $\mathrm{Ca}^{2+}+\mathrm{Mg}^{2+}$ and $\mathrm{Na}^{+}+\mathrm{K}^{+}$was used(Fig. 10c). The majority of the samples are above the 1:1 line, which indicates the weathering and dominance of carbonate weathering over silicate weathering in the study area (Sami 1992).

Additionally, the chloro-alkaline indices (CAI) postulated by Schöeller(1965) were used to interpret the ion-exchange process between groundwater and the geological medium during its travel times. The chloro-alkaline indices were determined from the formula below and expressed in meq/L

$\mathrm{CAI} 1=\frac{\mathrm{Cl}-(\mathrm{Na}+\mathrm{k})}{\mathrm{Cl}}$

$\mathrm{CAI} 2=\frac{\mathrm{Cl}-(\mathrm{Na}+\mathrm{K})}{\mathrm{SO}_{4}+\mathrm{HCO}_{3}+\mathrm{NO}_{3}}$

Cation exchange occurs when $\mathrm{Ca}^{2+}$ and $\mathrm{Mg}^{2+}$ in water are substituted by $\mathrm{Na}^{+}$of the aquifer material, leading to a higher $\mathrm{Na}^{+}$concentration in the water relative to $\mathrm{Ca}^{2+}$ and 

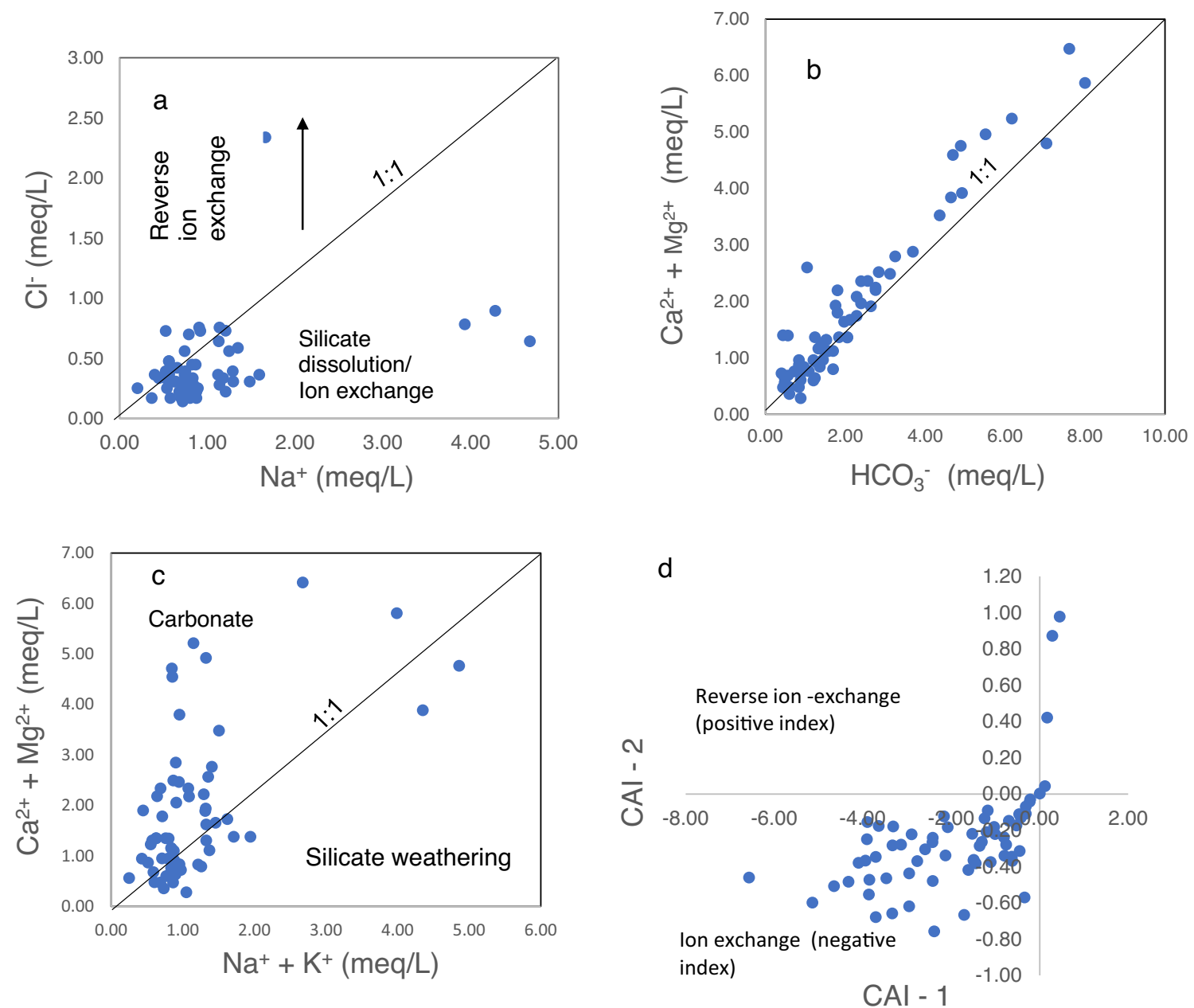

Fig. 10 a The plot of $\mathrm{Na}^{+}+\mathrm{Cl}^{-}(\mathrm{meq} / \mathrm{L}), \mathbf{b} \mathrm{Ca}^{2+}+\mathrm{Mg}^{2+}(\mathrm{meq} / \mathrm{L})$ versus $\mathrm{HCO}_{3}^{-}(\mathrm{meq} / \mathrm{L}), \mathbf{c} \mathrm{Na}^{+}+\mathrm{K}^{+}(\mathrm{meq} / \mathrm{L})$ versus $\mathrm{Ca}^{2+}+\mathrm{Mg}^{2+}(\mathrm{meq} / \mathrm{L})$, and d CAI- 1 versus CAI- 2 .

$\mathrm{Mg}^{2+}$ concentrations (Appello and Potsma 2005). Here, both CAI 1 and CAI 2 values are negative. According to Srinivasamoorthy et al. (2014), the negative CAI values are widely referred to as a cation-anion-exchange reaction or chloro-alkaline disequilibrium having low salt waters. On the contrary, reverse ion exchange occurs when $\mathrm{Na}^{+}$and $\mathrm{K}^{+}$in the water are substituted by $\mathrm{Ca}^{2+}$ and $\mathrm{Mg}^{2+}$ of the aquifer material. This instance indicates that $\mathrm{CA} 1$ values are positive. When there is no exchange between the ions and the aquifer material, CAI becomes zero and ion exchange reaches an equilibrium. From (Fig. 10d), the estimated CAI 1 and CAI 2 indices are all negative except for five samples that have positive values. The negative values explain the cation-exchange reaction in the aquifer, where new pore water dominated by $\mathrm{Na}^{+}$replaces the original pore water dominated by $\mathrm{Ca}^{2+}$ and $\mathrm{Mg}^{2+}$. This outcome leads to enrichment of $\mathrm{Na}^{+}$and decrease of $\mathrm{Ca}^{2+}$ and $\mathrm{Mg}^{2}$ concentrations in the groundwater. The cation-exchange reaction explaining this process is illustrated in Eq. (9) and (10) (Hem 1985)
$\mathrm{Na}_{2} \mathrm{X}+\mathrm{Ca}^{2+} \rightleftharpoons \mathrm{CaX}+2 \mathrm{Na}^{+}$

$\mathrm{Na}_{2} \mathrm{X}^{+}+\mathrm{Mg}^{2+} \rightleftharpoons \mathrm{Mg}^{2+}+2 \mathrm{Na}^{+}$

where $X$ is the aquifer material.

\section{Inverse geochemical modelling}

Inverse geochemical modelling was invoked to deduce the mass transfer reactions of different mineral phases that dissolve or precipitate in groundwater along its flow path. Here, inverse geochemical modelling was employed based on the following assumptions: (1) the water composition from the "initial" and "final" conditions evolve along the identical flow path, (2) hydrodynamic dispersion and diffusion processes do have little influence on the groundwater chemistry, (3) the chemical reactions are in steady state, and (4) the mineral species considered are available in the lithological materials ( $\mathrm{Zhu}$ 
et al. 2002). With this, the chemical composition of precipitation in Obuasi town (Akoto et al. 2011) was adopted and used as "initial" waters due to its proximity and similar climatic condition to the study area. The mean chemical parameters from each of the three generated hierarchical cluster analysis (i.e., Cluster 1, 2, and 3) were used as "final" water (Table 5). The clusters were redefined as group 1-group 3 for this exercise. Three models were run based on the three groups and the respective end-members are (1) local precipitation to group 1; (2) group 1 to group 2; and (3) group 2 to group 3. The mineral phases considered in this inverse model were selected based on the geology of the area. For instance, plagioclase, muscovite, chlorite, chalcedony, and K-feldspar minerals were selected to represent silicate mineral weathering in the area (Karikari et al. 2007). Kaolinite was included, because it is a weathering product of plagioclase (Appelo and Potsma 2005). Calcite and dolomite were included in the phase to account for carbonate weathering. Atmospheric $\mathrm{CO}_{2}$ was added in model 1 to explain infiltrating rainwater mixed with $\mathrm{CO}_{2}$ in contact with carbonate minerals, while $\mathrm{CaX} 2$ and $\mathrm{NaX}$ were added to represent cation exchange (Lyu et al. 2019). The mineral saturation indices (Fig. 8) and the hydrochemical evolution trends inferred from the cluster analysis were used as a guide to constrain the minerals' precipitation and dissolution processes in the inverse model. The inverse model was set up, so that the primary minerals such as dolomite, halite, muscovite, and plagioclase were allowed to undergo dissolution until saturation is reached, while kaolinite and chlorite were constrained to precipitate once they reached saturation state.

The results of the final inverse modelling are presented in (Table 6). The geochemical evolution of the initial solution, reactant phases, and final solution from group 1 waters to group 3 waters are summarised below:

In Model 1, the hydrogeochemical path is characteristic of the recharge area where infiltrating rainwater mixed with $\mathrm{CO}_{2}$ reacts with water and carbonate minerals. This releases $\mathrm{HCO}_{3}{ }^{-}$ions into the waters and explains the dominance of $\mathrm{Ca}-\mathrm{Mg}-\mathrm{HCO}_{3}$ in recharge areas. The recharge areas are found in the Bekwai municipality (Fig. 5) and water passing through this zone has a slightly lower mean $\mathrm{pH}$ of 5.98 (Table 5) relative to the other groups. The results from the inverse model 1 (Table 6) indicate the dissolution of gypsum, halite, dolomite, muscovite, and plagioclase. Furthermore, calcite was seen to be precipitated in this model due
Table 5 The mean concentrations of the three groups used in the inverse model

\begin{tabular}{lccccccccccc}
\hline & $\mathrm{pH}$ & $\mathrm{EC}$ & $\mathrm{TDS}$ & $\mathrm{HCO}_{3}^{-}$ & $\mathrm{Cl}^{-}$ & $\mathrm{SO}_{4}^{2-}$ & $\mathrm{NO}_{3}^{-}$ & $\mathrm{Ca}^{2+}$ & $\mathrm{Mg}^{2+}$ & $\mathrm{Na}^{+}$ & $\mathrm{K}^{+}$ \\
\hline Precipitation & 4.79 & 19.84 & 11.03 & 11.14 & 4.92 & 11.79 & 0.29 & 0.82 & 0.27 & 0.31 & 0.66 \\
Group 1 & 5.98 & 140.4 & 77.05 & 70.31 & 11.09 & 5.14 & 4.95 & 9.35 & 5.56 & 15.89 & 3.37 \\
Group 2 & 6.29 & 279.0 & 159.1 & 127.78 & 29.51 & 8.04 & 2.49 & 22.68 & 10.45 & 24.76 & 5.88 \\
Group 3 & 6.95 & 526.08 & 290.0 & 329.08 & 17.61 & 18.77 & 1.53 & 44.03 & 27.61 & 45.25 & 3.57 \\
\hline
\end{tabular}

NB: Chemical composition of rainwater in Ramia-Obuasi was adopted from Akoto et al. (2011)

Table 6 Results of the inverse geochemical modelling along the flow path (precipitation-Group 3)

\begin{tabular}{lllll}
\hline Mineral phases & Precipitation to Group1 & Group 1 to Group2 & $\begin{array}{l}\text { Group 2 to chemi- } \\
\text { cal }\end{array}$ & Group 3 formula \\
\hline Plagioclase & $1.15 \mathrm{E}-04$ & $1.17 \mathrm{E}-04$ & $1.43 \mathrm{E}-04$ & $\mathrm{Na}_{0 \cdot 62} \mathrm{Ca}_{0 \cdot 38} \mathrm{Al}_{1 \cdot 38} \mathrm{Si}_{2.62} 0_{8}$ \\
$\mathrm{CaX} 2$ & $-2.11 \mathrm{E}-04$ & $-2.43 \mathrm{E}-04$ & $-2.45 \mathrm{E}-04$ & $\mathrm{CaX} 2$ \\
$\mathrm{NaX}$ & $4.22 \mathrm{E}-04$ & $4.85 \mathrm{E}-04$ & $4.90 \mathrm{E}-04$ & $\mathrm{NaX}$ \\
Calcite & $-2.86 \mathrm{E}-04$ & $-2.13 \mathrm{E}-04$ & $-2.09 \mathrm{E}-03$ & $\mathrm{CaCO}_{3}$ \\
Muscovite & $3.46 \mathrm{E}-05$ & $6.42 \mathrm{E}-05$ & $5.24 \mathrm{E}-05$ & $\mathrm{KAl}_{3} \mathrm{Si}_{3} \mathrm{O}_{10}(\mathrm{OH})_{2}$ \\
Gypsum & $3.92 \mathrm{E}-05$ & $3.02 \mathrm{E}-05$ & $3.02 \mathrm{E}-05$ & $\mathrm{CaSO}_{4}$ \\
Chlorite & - & $-1.45 \mathrm{E}-04$ & $-1.77 \mathrm{E}-04$ & $\mathrm{Mg}_{5} \mathrm{Al}_{2} \mathrm{~S}_{\mathrm{i} 3} \mathrm{O}_{10}(\mathrm{OH})_{8}$ \\
Kaolinite & - & $-3.93 \mathrm{E}-05$ & - & $\mathrm{Al}_{2} \mathrm{Si}_{2} \mathrm{O}_{5}(\mathrm{OH})_{4}$ \\
K-feldspar & $1.04 \mathrm{E}-04$ & & - & $\mathrm{KAlS}_{\mathrm{i} 3} \mathrm{O}_{8}$ \\
Halite & $1.10 \mathrm{E}-03$ & $7.99 \mathrm{E}-04$ & - & $\mathrm{NaCl}$ \\
Dolomite & $2.18 \mathrm{E}-04$ & $9.27 \mathrm{E}-04$ & - & $\left.\mathrm{CaMg}_{(\mathrm{CO}}\right)_{2}$ \\
CO & (g) & - & - & $\mathrm{CO}_{2}$ \\
Chalcedony & $-2.08 \mathrm{E}-04$ & - & - & $\mathrm{SiO}_{2}$ \\
\hline
\end{tabular}

NB: PHREEQC v 3.6.2 program (Parkhust and Appelo 2013) was for the inverse model calculations. The thermodynamic database used: phreeqc.dat values are in mol/ $/ \mathrm{kg} \mathrm{H}_{2} \mathrm{O}$. Positive mole transfer value means mass entering the solution (dissolution) and negative-phase mole transfer indicates mass leaving the solution (precipitation) 
to the dissolution of gypsum. This is known as the common ion effect and is broadly discussed by Langmuir (1997). The inverse modelling describing model 1 is represented as

Rainwater $+\mathrm{CO}_{2}$ (gas) + muscovite + dolomite

+ halite + gypsum + plagioclase $\rightarrow \mathrm{Ca}-\mathrm{Mg}$

$-\mathrm{HCO}_{3}$ waters + calcite + chalcedony.

Model 2 describes the evolutional path from group 1 to group 2 (transition water types). The group 2 end-members constitute mixed cations and bicarbonate. The conceptual model describing groundwater evolution from group 1 waters to group 2 waters is mainly controlled by topography and water-rock interaction, as shown in Fig. 11. Inverse modelling describing model 2 is written as

$\left(\mathrm{Ca}-\mathrm{Mg}-\mathrm{HCO}_{3}\right.$ waters $)+$ Plagioclase

+ muscovite + gypsum

+ halite + dolomite

$+\mathrm{NaX}$ (from cation exchange) $\rightarrow \mathrm{Na}-\mathrm{Ca}-\mathrm{Mg}$

$-\mathrm{HCO}_{3}$ waters (transition waters)

$+\mathrm{CaX} 2(\mathrm{Ca}$ loss for ion exchange)

+ kaolinite + chlorite.

Model 3 is an evolutional path from group 2 waters to group 3 waters $\left(\mathrm{Na}-\mathrm{HCO}_{3}\right)$. Group 3 waters are mainly found in discharge areas in the downward part of the Bosome Freho district. As groundwater moves towards discharge areas, a large excess of $\mathrm{Na}^{+}$relative to $\mathrm{Ca}^{2+}$ is observed, giving a clue of ion exchange. The $\mathrm{Ca}^{2+}$ released into the groundwater due to calcite dissolution present in the Tarkwaian rocks is exchanged for the $\mathrm{Na}^{+}$in discharge areas associated with clay sediments (Appelo and Potsma 2005). Kaolinite and Na-Montmorillonite clays have been reported to be present in aquifers around Lake Bosumtwi craters, which is also a discharge area of this present study (Loh et al. 2016). Inverse geochemical modelling explaining model 3 is written as

$$
\begin{aligned}
& \mathrm{Na}-\mathrm{Ca}-\mathrm{Mg}-\mathrm{HCO}_{3} \text { waters }+ \text { plagioclase }+ \text { muscovite } \\
& + \text { gypsum }+\mathrm{NaX} \text { (from cation exchange }) \rightarrow\left(\mathrm{Na}-\mathrm{HCO}_{3}\right) \\
& +\mathrm{CaX}(\mathrm{Ca} \text { loss for ion exchange })+\text { calcite. }
\end{aligned}
$$

The results from the inverse geochemical modelling general show the dissolution of carbonate minerals, silicate minerals, and ion exchange along the groundwater flow path. These findings support the results obtained from hydrochemical analysis and the various ionic plots.

\section{Water quality index (WQI)}

The water quality index (WQI) is a rating criterion applied to interpret the general quality of groundwater sampled in a particular location. It quantifies different water parameters into a single value for easier interpretation regarding its quality (Tyagi et al. 2017). There are considerable amounts of WQI methods used in other countries after the pioneering WQI developed by Horton (1965) in USA. In
Fig. 11 Conceptual model of hydrochemical flow evolution (Group 1-Group 3) and ion exchange in the study area. Evolution distance $(\mathrm{km})$ from Bekwai (recharge areas) to Bosome Freho (discharge areas) is also shown

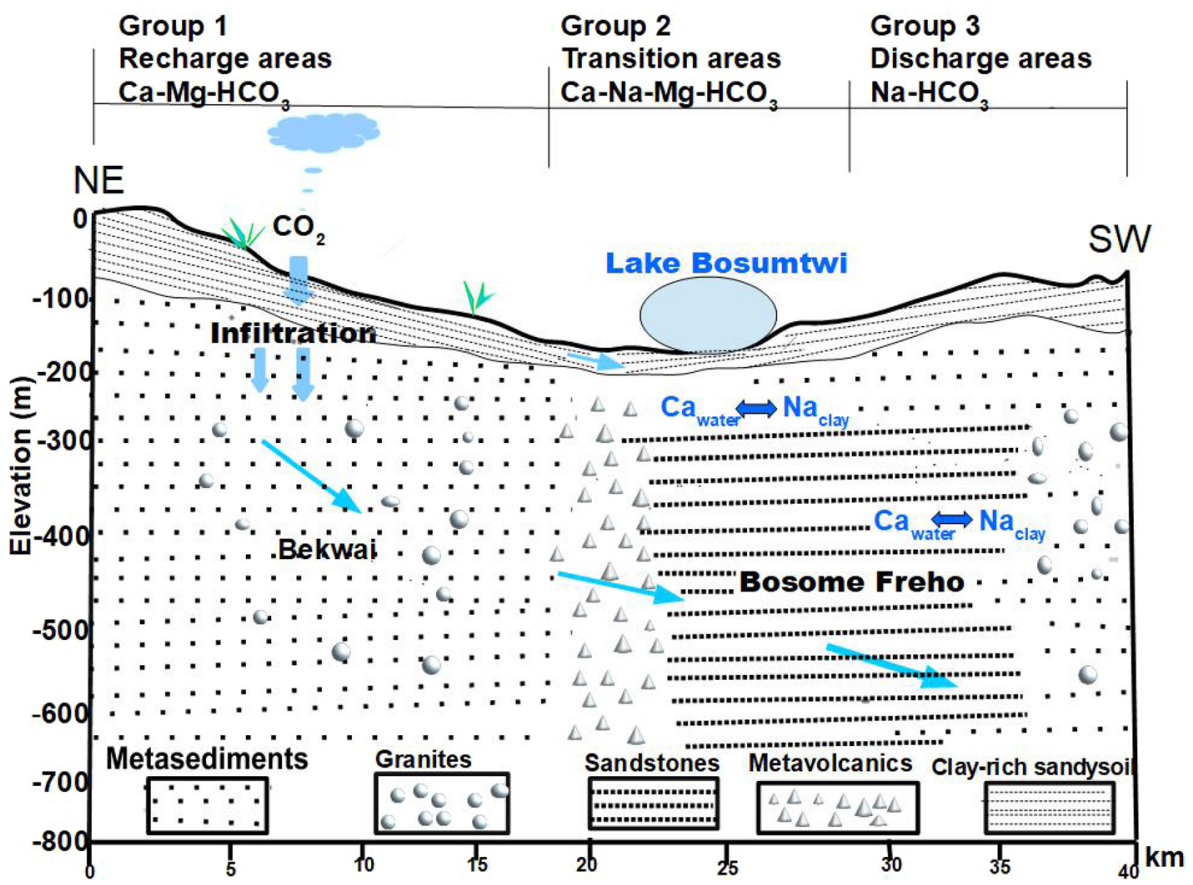


this study, the WQI proposed by Brown et al. (1972) was used to evaluate 18 parameters for drinking water suitability in the area. This method is based on assigning weights to the individual groundwater parameters (wi) according to the relative importance of the WHO (2017) drinking water guidelines. For example, zinc is not rated important in the WHO drinking water guidelines, so it is assigned a minimum weight value of 1. Elevated fluoride, nitrate, arsenic, and lead concentrations in drinking water are a grave concern to humanity, so they are assigned a maximum weight value of 5 (Table 7). The other parameters, such as $\mathrm{Ca}^{2+}$, $\mathrm{Mg}^{2+}$, TDS, $\mathrm{Na}^{+}$, etc., are given different weight values (1-5) according to their importance. The individual weights are then summed together to estimate the relative weight (Wi) expressed in Eq. (14)

$\mathrm{Wi}=\frac{\mathrm{wi}}{\sum_{\mathrm{i}=1}^{\mathrm{n}} \mathrm{wi}}$.

Wi is the relative weight, wi is the individual parameter of a sample at a given location, and $\mathrm{n}$ is the total number of parameters.

In the next step, the concentration of the individual parameter is divided by the WHO standard limit of that parameter and multiplied by 100 to obtain the quality rating (qi), expressed in Eq. (15)

Table 7 WQI based on the relative weights and weights of the parameters

\begin{tabular}{|c|c|c|c|}
\hline Parameters & WHO guidelines & Weight (wi) & $\begin{array}{l}\text { Relative } \\
\text { weight } \\
\text { (Wi) }\end{array}$ \\
\hline $\mathrm{pH}$ & 7.5 & 4 & 0.0656 \\
\hline TDS & 1000 & 4 & 0.0656 \\
\hline $\mathrm{Na}^{+}(\mathrm{mg} / \mathrm{L})$ & 200 & 2 & 0.0328 \\
\hline $\mathrm{K}^{+}(\mathrm{mg} / \mathrm{L})$ & 30 & 2 & 0.0328 \\
\hline $\mathrm{Ca}^{2+}(\mathrm{mg} / \mathrm{L})$ & 200 & 2 & 0.0328 \\
\hline $\mathrm{Mg}^{2+}(\mathrm{mg} / \mathrm{L})$ & 150 & 2 & 0.0328 \\
\hline $\mathrm{Cl}^{-}(\mathrm{mg} / \mathrm{L})$ & 250 & 3 & 0.0492 \\
\hline $\mathrm{SO}_{4}{ }^{2-}(\mathrm{mg} / \mathrm{L})$ & 250 & 3 & 0.0492 \\
\hline $\mathrm{PO}_{4}{ }^{3-}(\mathrm{mg} / \mathrm{L})$ & 30 & 4 & 0.0656 \\
\hline $\mathrm{NO}_{2}^{-}(\mathrm{mg} / \mathrm{L})$ & 3 & 4 & 0.0656 \\
\hline $\mathrm{NO}_{3}^{-}(\mathrm{mg} / \mathrm{L})$ & 50 & 5 & 0.0820 \\
\hline $\mathrm{F}^{-}(\mathrm{mg} / \mathrm{L})$ & 1.5 & 5 & 0.0820 \\
\hline $\mathrm{Mn}^{2+}(\mathrm{mg} / \mathrm{L})$ & 0.1 & 4 & 0.0656 \\
\hline $\mathrm{Fe}(\mathrm{mg} / \mathrm{L})$ & 0.3 & 4 & 0.0656 \\
\hline $\mathrm{Cu}(\mathrm{mg} / \mathrm{L})$ & 2 & 2 & 0.0328 \\
\hline As $(m g / L)$ & 0.01 & 5 & 0.0820 \\
\hline $\mathrm{Pb}(\mathrm{mg} / \mathrm{L})$ & 0.01 & 5 & 0.0820 \\
\hline $\mathrm{Zn}(\mathrm{mg} / \mathrm{L})$ & 3 & 1 & 0.0164 \\
\hline
\end{tabular}

$\mathrm{qi}=\frac{\mathrm{Ci}}{\mathrm{Si}} \times 100$,

where qi is the quality rating, $\mathrm{Ci}$, is the concentration of the individual parameter, and $\mathrm{Si}$ is the WHO standard limit value of the individual parameter.

The water quality index (WQI) of each location is finally determined from the subindex Si in Eqs. (16) and (17)

$\mathrm{SI}_{\mathrm{i}}=\mathrm{Wi} \times \mathrm{qi}$,

where $\mathrm{SI}_{\mathrm{i}}$ is the subindex

$\mathrm{WQI}=\sum$ SIi.

An adapted version of the WQI classification scheme proposed by Sahu and Sikdar (2008) was used for this study. The classification rates "excellent water" for WQI values between 0 and 50; "good water" from 51 to 100 ; "poor water" from 101 to 200; "very poor water" (201-300), and "unsuitable drinking water" (> 300). The estimated WQI in the study area ranges from 13.5 to 53.9, with Bekwai Municipality showing "excellent water quality" and "good water" in few areas. Similarly, about $92 \%$ of the groundwater in the Bosome Freho District shows "excellent water", while 8\% of the water exhibits "good water quality" (Fig. 12). Based on the WQI values obtained vis-a-vis the geology of the study area, the water quality shows that the Birimian and the associated Eburnean Plutonic Suite rocks mostly hold "excellent water", while the Tarkwaian sedimentary rocks hold "excellent water" and "good water".

\section{Assessment of groundwater quality for irrigation use}

The use of groundwater for irrigation is pervasive in rural agricultural areas. Thus, groundwater for irrigation can be evaluated using the two main methods-salinity hazards and sodium adsorption ratio (SAR). The high amount of salts in groundwater resulting from silicate weathering, which releases high amounts of $\mathrm{Na}^{+}$and associated $\mathrm{Cl}^{-}$, can have detrimental effects on plant growth (Hem, 1985). Soils containing high quantities of saltwater can lower the osmotic pressure and decrease soil permeability as well as water uptake by plant roots (Zaidi et al. 2015). Based on this, a Wilcox diagram, which is salinity hazard represented by electrical conductivity on the $\mathrm{x}$-axis against sodium adsorption ratio (SAR) measured by the relative amounts of $\mathrm{Na}^{+}, \mathrm{Ca}^{2+}$, and $\mathrm{Mg}^{2+}$ on the $y$ axis, was used (USSL 1954). From Fig. 13, all the groundwater samples are within the low sodium hazard (S1) zone and within the low-to-medium salinity hazard $(\mathrm{C} 1-\mathrm{C} 2)$ zone. As expected, the cluster 1 type of low ionic water composition falls in the $\mathrm{C} 1-\mathrm{S} 1$ group, which is characterised by low sodium 


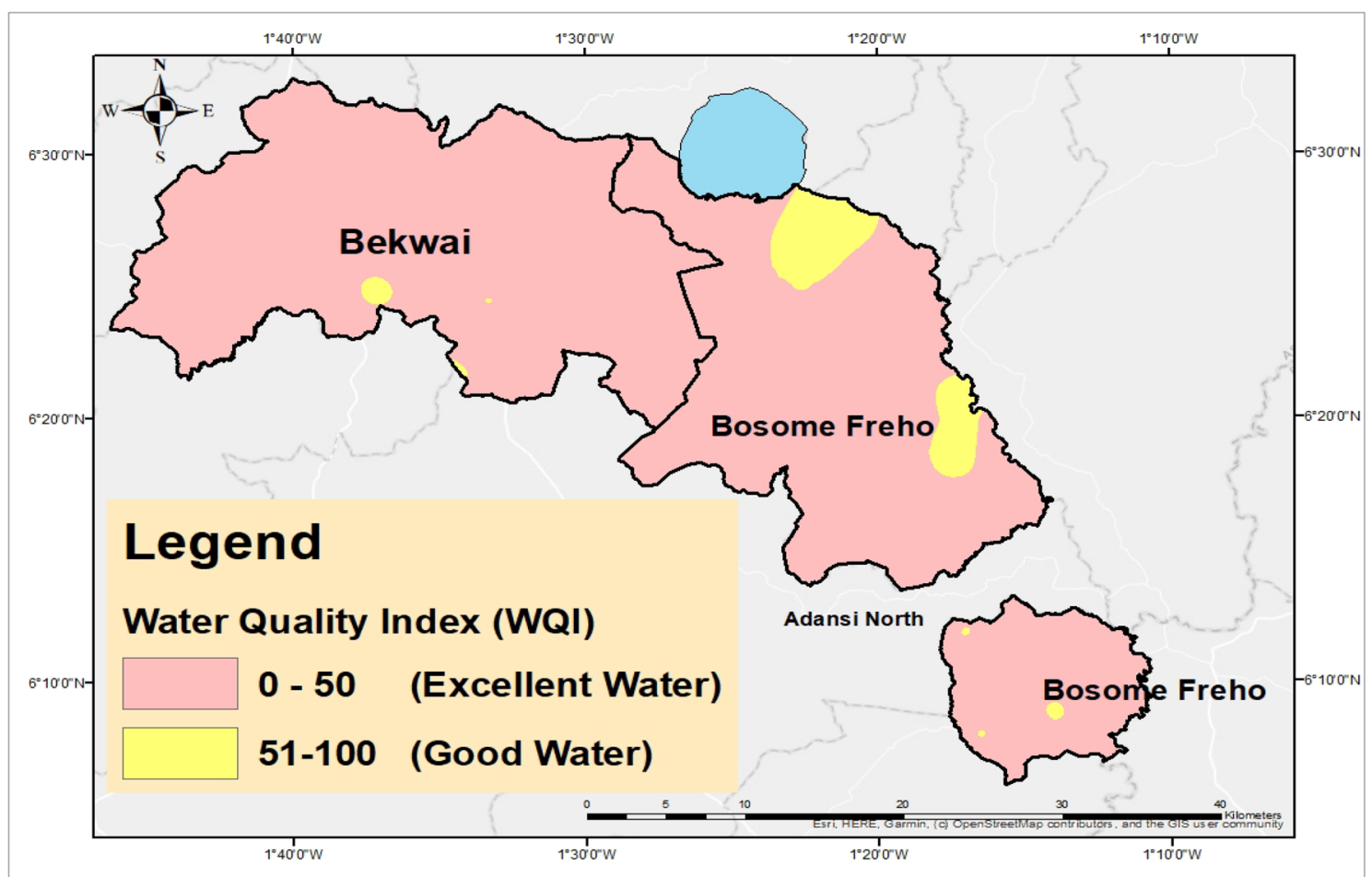

Fig. 12 Water quality index (WQI) distribution map of the study area

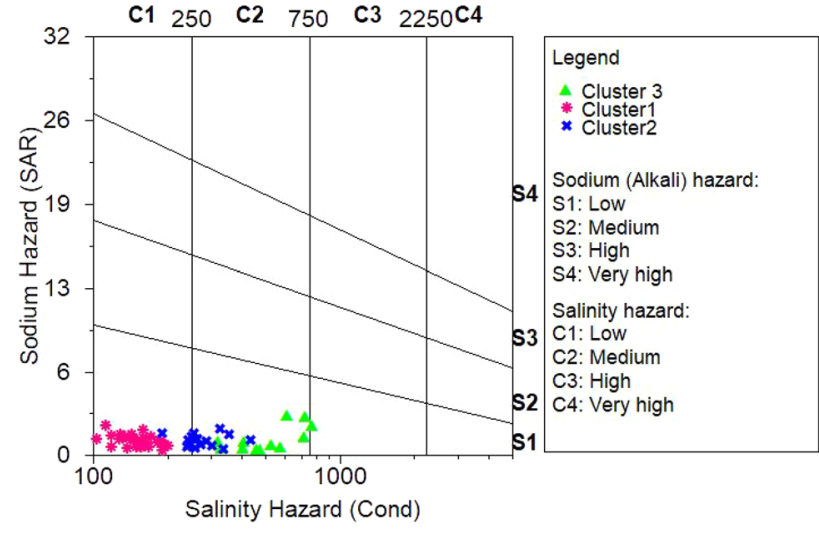

Fig. 13 Wilcox diagram showing the salinity and sodium hazards of groundwater

and salinity hazards. Nearly, all the cluster 2 and 3 types typically of moderate ionic waters are within the (S1-C2) group, which suggests that groundwater in the study area is generally suitable for irrigation without causing any danger to crops.

\section{Conclusions}

This study has investigated the use of multivariate statistics and conventional hydrogeochemical diagrams in understanding the geochemical processes that impact groundwater chemistry in the Bekwai municipality and Bosome Freho district of Ghana. Hierarchical cluster analysis (HCA) in combination with principal component analysis was applied on 64 groundwater samples to classify recharge and discharge areas and the flow pattern of the area. The results of the Q-mode HCA exhibit three spatial groundwater clusters, each with different groundwater flow regimes. Cluster 1 (recharge area) is found in high topographical areas and dominated by $\mathrm{Ca}-\mathrm{Mg}-\mathrm{HCO}_{3}$ with low TDS and EC values, which evolves to cluster 2 (transition area) with $\mathrm{Ca}-\mathrm{Na}-\mathrm{HCO}_{3}$, or $\mathrm{Na}-\mathrm{Ca}-\mathrm{HCO}_{3}$ mixed water types; and finally to cluster 3 (discharge area) with $\mathrm{Na}-\mathrm{Ca}-\mathrm{Mg}-\mathrm{HCO}_{3}-\mathrm{Cl}$ water types and high $\mathrm{EC}$ and TDS in low topographical areas. The discharge areas are in the southern part and northeastern part towards Lake Bosumtwi. The principal component analysis (PCA) suggests different sets of geochemical processes occurring in the aquifer. These have high positive loadings of $\mathrm{Na}^{+}, \mathrm{Ca}^{2+}, \mathrm{Mg}^{2+}$, and 
$\mathrm{HCO}_{3}{ }^{-}$, which reflect the underlying geology of the area. The high loadings of $\mathrm{Na}^{+}$and $\mathrm{HCO}_{3}{ }^{-}$suggest silicate mineral dissolutions, such as feldspars and micas, which are found in the intrusive granites of the area.

Similarly, $\mathrm{Ca}^{2+}$ and $\mathrm{Mg}^{2+}$ loadings reflect the weathering of carbonate minerals, such as calcite, chlorite, and biotite, in the Birimian and Tarkwaian rocks of the area. This is in line with the results obtained from the Gibbs diagram, in which groundwater-rock interaction is a dominant process occurring in the aquifer. The low loadings of $\mathrm{F}^{-}, \mathrm{Cl}^{-}, \mathrm{SO}_{4}{ }^{2-}$, and $\mathrm{NO}_{3}{ }^{-}$in the groundwater indicate that anthropogenic activities have little influence on groundwater chemistry in the area. The various ionic plots and the chloro-alkaline indices reveal silicate mineral weathering and cation exchange in the aquifer where the original pore water dominated by $\mathrm{Ca}^{2+}$ and $\mathrm{Mg}^{2+}$ is replaced by $\mathrm{Na}^{+}$causing a decrease of the former in the water. The saturation indices suggest that nearly all the groundwaters are undersaturated with respect to calcite and dolomite, indicating the dissolution of carbonates minerals found in the Birimian and Tarkwaian rocks. Based on the Wilcox diagram and the water quality index, the groundwater in the study area is suitable for irrigation and drinking water purposes. This is the first hydrochemical study to ascertain the factors controlling groundwater chemistry in the Bosome Freho District and Bekwai Municipality. The generated groundwater chemistry flow patterns can be satisfactorily used to predict the general flow pattern of the area and will serve as a first step towards the construction of a conceptual framework of the area using groundwater models.

Supplementary Information The online version contains supplementary material available at https://doi.org/10.1007/s12665-021-10081-2.

Acknowledgements The authors would like to thank Dr Millicent Obeng at the University of Education Winneba, Ghana for her guidance and support. Special thanks go to Bernand Fosu Frimpong and Fredrick Gyasi Damptey both at Brandenburg University of Technology, Cottbus, Germany for their invaluable contributions.

Funding Open Access funding enabled and organized by Projekt DEAL.

\section{Declarations}

Conflict of interest The authors declare no conflict of interest.

Open Access This article is licensed under a Creative Commons Attribution 4.0 International License, which permits use, sharing, adaptation, distribution and reproduction in any medium or format, as long as you give appropriate credit to the original author(s) and the source, provide a link to the Creative Commons licence, and indicate if changes were made. The images or other third party material in this article are included in the article's Creative Commons licence, unless indicated otherwise in a credit line to the material. If material is not included in the article's Creative Commons licence and your intended use is not permitted by statutory regulation or exceeds the permitted use, you will need to obtain permission directly from the copyright holder. To view a copy of this licence, visit http://creativecommons.org/licenses/by/4.0/.

\section{References}

Adimalla N (2020a) Controlling factors and mechanism of groundwater quality variation in semiarid region of South India: an approach of water quality index (WQI) and health risk assessment (HRA). Environ Geochem Health 42(6):1725-1752. https://doi.org/10. 1007/s10653-019-00374-8

Adimalla N (2020b) Assessment and mechanism of fluoride enrichment in groundwater from the hard rock terrain: a multivariate statistical approach. Geochem Int 58(4):456-471. https://doi.org/ 10.1134/S0016702920040060

Adimalla N (2021) Application of the entropy weighted water quality index (EWQI) and the pollution index of groundwater (PIG) to assess groundwater quality for drinking purposes: a case study in a rural area of Telangana State, India. Arch Environ Contam Toxicol 80:31-40. https://doi.org/10.1007/s00244-020-00800-4

Adimalla N, Li P, Venkatayogi S (2018) Hydrogeochemical evaluation of groundwater quality for drinking and irrigation purposes and integrated interpretation with water quality index studies. Environ Process 5(2):363-383. https://doi.org/10.1007/s40710-018-0297

Adimalla N, Qian H, Nandan MJ (2020a) Groundwater chemistry integrating the pollution index of groundwater and evaluation of potential human health risk: a case study from hard rock terrain of south India. Ecotoxicol Environ Saf 206:111217. https://doi. org/10.1016/j.ecoenv.2020.111

Adimalla N, Qian H, Li P (2020b) Entropy water quality index and probabilistic health risk assessment from geochemistry of groundwaters in hard rock terrain of Nanganur County, South India. Geochemistry 80(4):125544. https://doi.org/10.1016/j.chemer.2019. 125544

Akoto O, Darko G, Nkansah MA (2011) Chemical composition of rainwater over a mining area in Ghana. Int $\mathbf{J}$ Environ Res 5(4):847-854

Amu-Mensah F, Amu-Mensah M, Akrong OM, Addico G, Darko H (2019) Hydrology of the major water sources of Lake Bosumtwe in Ghana. West Afr J Appl Ecol. https://doi.org/10.13140/RG.2. 2.27485 .97761

Anim-Gyampo M, Anornu GK, Appiah-Adjei EK, Agodzo SK (2018) Hydrogeochemical evolution and quality assessment of groundwater within the Atankwidi basin: the case of northeastern Ghana. Arab J Geosci. https://doi.org/10.1007/s12517-018-3753-6

Appelo CAJ, Postma D (2005) Groundwater, geochemistry and pollution., 2nd edn. A.A Balkema Publishers

Banoeng-Yakubu B, Yidana SM, Ajayi JO, Loh Y, Aseidu D (2011) Hydrogeology and groundwater resources of Ghana: a review of the hydrogeology and hydrochemistry of Ghana. McMann JM (ed) Potable Water and Sanitation, Vol 142. Nova Science New York

Barcelona MJ, Gibb JP, Helfrich, John A, Garske, EE (1985) A practical guide for groundwater sampling

Bartos TT, Ogle KM (2002) Water quality and environmental isotopic analyses of groundwater samples collected from the Wasatch and Fort Union formations in areas of coalbed methane development: implications to recharge and groundwater flow, eastern Powder River Basin, Wyoming (No. 2). In: US Department of the Interior, U.S. Geological Survey. https://pubs.usgs.gov/wri/wri024045/ htms/report2.htm

Brako BA, Foli G, Amedjoe C, Gawu SK (2020) Petrographic study of some paleoproterozoic sedimentary rocks in the Chagupana and Tarkwa Areas of Ghana. Int J Geogr Geol 9(1):38-54. https://doi. org/10.18488/journal.10.2020.91.38.54 
Brown RM, Mccleiland NJ, Deiniger RA, O'Connor MF (1972) Water quality index-crossing the physical barrier,(Jenkis, $\mathrm{SH}$, ed.) In: Proc. In Intl. Conf. on water poll. Res. Jerusalem (Vol. 6, pp. 787-797)

Carrier MA, Lefebvre R, Racicot J, Asare EB (2008) Northern Ghana hydrogeological assessment project. Access to Sanitation and Safe Water: Global Partnerships and Local Actions-Proceedings of the 33rd WEDC International Conference

Clark I (2015) Groundwater geochemistry and isotopes. Groundw Geochem Isotop. https://doi.org/10.1201/b18347

Cobbinah PB, Okyere DK, Gaisie E (2016) Population growth and water supply. https://doi.org/10.4018/978-1-5225-0187-9.ch012

Dapaah-Siakwan S, Gyau-Boakye P (2000) Hydrogeologic framework and borehole yields in Ghana. Hydrogeol J. https://doi. org/10.1007/PL00010976

Elbra T, Kontny A, Pesonen LJ, Schleifer N, Schell C (2007) Petrophysical and paleomagnetic data of drill cores from the Bosumtwi impact structure. Met Planet Sci Ghana. https://doi. org/10.1111/j.1945-5100.2007.tb01078.x

Feybesse JL, Billa M, Guerrot C, Duguey E, Lescuyer JL, Milesi JP, Bouchot V (2006) The Paleoproterozoic Ghanaian province: geodynamic model and ore controls, including regional stress modelling. Precambr Res. https://doi.org/10.1016/j.precamres. 2006.06.003

Freeze RA, Cherry JA (1979) Groundwater (No. 629.1 F7). PrenticeHall, Englewood Cliffs, NJ 07632

Ghana Statistical Service (2014) District analytical report: Bosome Freho District. https://www2.statsghana.gov.gh/docfiles/2010_ District_Report/Ashanti/BOSOME_FREHO.pdf

Gibbs RJ (1970) Mechanisms controlling world water chemistry. Science. https://doi.org/10.1126/science.170.3962.1088

Güler C, Thyne GD, McCray JE, Turner AK (2002) Evaluation of graphical and multivariate statistical methods for classification of water chemistry data. Hydrogeol J. https://doi.org/10.1007/ s10040-002-0196-6

Hagmaier JL (1971) Groundwater flow, hydrochemistry, and uranium deposition in the Powder River Basin, Wyoming. Theses and Dissertations. 115. https://commons.und.edu/theses/115

Hem JD (1985) Study and interpretation of the chemical characteristics of natural water. US Geological Survey Water-Supply Paper.

Hirdes W, Nunoo B (1994) The Proterozoic paleoplacers at Tarkwa Gold Mine, S.W. Ghana: sedimentology, mineralogy and precise age dating of the main reef and west reef, and bearing of the investigations on source area aspects. Geologsche Jahrbuch Reihe D 100:247-311

Hölting B, Coldewey WG (2019) Hydrogeology, Springer textbooks in earth sciences, geography and environment Berlin, Heidelberg. https://doi.org/10.1007/978-3-662-56375-5

Horton RK (1965) An Index number system for rating water Quality. J Water Pollut Control Federat Cont Fed 37(3):300-305

Hounslow A (1995) Water quality data: analysis and interpretation. CRC Press. https://doi.org/10.1201/9780203734117

Karikari F, Ferriere L, Koeberl C, Reimold WU, Mader D (2007) Petrography, geochemistry, and alteration of country rocks from the Bosumtwi impact structure Ghana. Meteorit Planet Sci 42(4-5):513-540

Karro E, Marandi A, Vaikmäe R, Uppin M (2009) Chemical peculiarities of the Silurian-Ordovician and Cambrian-Vendian aquifer systems in Estonia: an overview of hydrochemical studies. Eston J Earth Sci. https://doi.org/10.3176/earth.2009.4.12

Kim KH, Yun ST, Park SS, Joo Y, Kim TS (2014) Model-based clustering of hydrochemical data to demarcate natural versus human impacts on bedrock groundwater quality in rural areas, South Korea. J Hydrol. https://doi.org/10.1016/j.jhydrol.2014.07.055
Langmuir D (1997) Aqueous environmental geochemistry No. 551.48 L3

Leube A, Hirdes W, Mauer R, Kesse GO (1990) The early Proterozoic Birimian Supergroup of Ghana and some aspects of its associated gold mineralisation. Precambr Res 46(1-2):139-165

Leybourne MI, Goodfellow WD (2010) Geochemistry of surface waters associated with an undisturbed $\mathrm{Zn}-\mathrm{Pb}$ massive sulfide deposit: water-rock reactions, solute sources and the role of trace carbonate. Chem Geol 279(1-2):40-54

Li P, Tian R, Liu R (2019) Solute geochemistry and multivariate analysis of water quality in the guohua phosphorite mine, Guizhou Province China. Expos Health. https://doi.org/10.1007/ s12403-018-0277-y

Loh YS, Yidana M, Banoeng-Yakubo B, Sakyi PA, Addai MO, Asiedu DK (2016) Determination of the mineral stability field of evolving groundwater in the Lake Bosumtwi impact crater and surrounding areas. J Afr Earth Sc 121:286-300

Loh YS, Akurugu BA, Manu E, Aliou AS (2020) Assessment of groundwater quality and the main controls on its hydrochemistry in some Voltaian and basement aquifers, northern Ghana. Groundw Sustain Dev. https://doi.org/10.1016/j.gsd.2019.100296

Lyu M, Pang Z, Yin L, Zhang J, Huang T, Yang S, Li Z, Wang X, Gulbostan $T$ (2019) The control of groundwater flow systems and geochemical processes on groundwater chemistry: a case study in Wushenzhao Basin NW China. Water 11(4):790

Marandi A, Polikarpus M, Jõeleht A (2013) A new approach for describing the relationship between electrical conductivity and major anion concentration in natural waters. Appl Geochem. https://doi.org/10.1016/j.apgeochem.2013.09.003

Meybeck M (1987) Global chemical weathering of surficial rocks estimated from river dissolved loads. Am J Sci. https://doi.org/10. 2475/ajs.287.5.401

Moon PA, Mason D (1967) The geology of 1/4 field sheets 129 and 131, Bompata S.W. and N.W, Ghana. Geol Surv Bull 31:1-51

Mumin AH, Fleet ME (1994) Evolution of gold mineralisation in the Ashanti Gold Belt, Ghana: evidence from carbonate compositions and parageneses. Mineral Petrol 55(4):265-280

Nkansah MA, Ephraim JH (2009) Chemical quality of groundwater drawn from boreholes in the Ashanti Region of Ghana. IAHS Publ 334(2009):36-39

Nordstrom DK (2011) Sulfide Mineral Oxidation. In: Thiel V, Reitner J (eds) Encyclopedia of geobiology. Encyclopedia of earth sciences series. Springer, Dordrecht. https://doi.org/10.1007/978-1-40209212-1 19

Ophori DU, Toth J (1989) Patterns of ground-water chemistry, Ross Creek Basin, Alberta, Canada. Groundwater 27(1): 20-26. https:// ngwa.onlinelibrary.wiley.com/doi/epdf/10.1111/j.1745-6584. 1989.tb00003.x

Osei-Nuamah I, Appiah-Adjei EK (2017) Hydrogeological evaluation of geological formations in Ashanti Region, Ghana. J Sci Ad Technol 37(1):34-50. https://doi.org/10.4314/just.v37i1.4

Parkhurst DL, Appelo CA (2013) Description of input and examples for PHREEQC version 3: a computer program for speciation, batchreaction, one-dimensional transport, and inverse geochemical calculations (No. 6-A43). U.S. Geological Survey.

Raiber M, White PA, Daughney CJ, Tschritter C, Davidson P, Bainbridge SE (2012) Three-dimensional geological modelling and multivariate statistical analysis of water chemistry data to analyse and visualise aquifer structure and groundwater composition in the Wairau Plain, Marlborough District, New Zealand. J Hydrol. https://doi.org/10.1016/j.jhydrol.2012.01.045

Rusydi AF (2018) Correlation between conductivity and total dissolved solid in various type of water: a review. IOP Conf Ser Earth Environ Sci. https://doi.org/10.1088/1755-1315/118/1/012019 
Sahu P, Sikdar PK (2008) A hydrochemical framework of the aquifer in and around East Kolkata Wetlands, West Bengal. India Environ Geol. https://doi.org/10.1007/s00254-007-1034-x

Sami K (1992) Recharge mechanisms and geochemical processes in a semi-arid sedimentary basin, Eastern Cape, South Africa. Journal of Hydrology. https://doi.org/10.1016/0022-1694(92)90193-Y

Schöeller H (1965) Geochemistry of groundwater. groundwater studies-an international guide for research and practice. UNESCO, Chapter 15, Paris, pp 1-18

Sharma MK, Kumar M (2020) Sulphate contamination in groundwater and its remediation: an overview. Environ Monit Assess. https:// doi.org/10.1007/s10661-019-8051-6

Smith AJ, Henry G, Frost-Killian S (2016) A review of the Birimian Supergroup-and Tarkwaian Group-hosted gold deposits of Ghana. Episodes 39(2):177-197. https://doi.org/10.18814/epiiugs/2016/ v39i2/95775

SNC-Lavalin/INRS (2011) Hydrogeological assessment project of the Northern Regions of Ghana (HAP). Final Tech Rep I(December):383-403. https://doi.org/10.1016/S1570-8705(03) 00040-4

Srinivasamoorthy K, Gopinath M, Chidambaram S, Vasanthavigar M, Sarma VS (2014) Hydrochemical characterisation and quality appraisal of groundwater from Pungar sub basin, Tamilnadu. India J King Saud Univ Sci. https://doi.org/10.1016/j.jksus.2013.08.001

Tay CK, Dorleku M, Koranteng SS (2018) Hydrochemical evolution of ground and surface water within the Amansie and Adansi districts of the Ashanti Region, Ghana. West Afr J Appl Ecol 26(1):108-133

Tran TQ, Banning A, Wisotzky F, Wohnlich S (2020) Mine water hydrogeochemistry of abandoned coal mines in the outcropped Carboniferous formations, Ruhr Area, Germany. Environ Earth Sci. https://doi.org/10.1007/s12665-020-8821-z
Tyagi S, Sharma B, Singh P, Dobhal R (2017) Water quality assessment in terms of the Water Quality Index. Int Res J Eng Technol. https://doi.org/10.12691/ajwr-1-3-3

UN (2010) The human right to water and sanitation. In: Sixty-four general assembly Agenda item 48, A/RES/64/292. https://www. un.org/ga/search/view_doc.asp?symbol=A/RES/64/292

United States Salinity Laboratory Staff (1954) Diagnosis and Improvement of Saline and Alkaline Soils. Agriculture Handbook No 60. In Agriculture Handbook No 60. https://doi.org/10.2136/sssaj 1954.03615995001800030032x

WHO (World Health Organization) (2017) Guidelines for DrinkingWater Quality: Fourth Edition Incorporating the First Addendum 978-92-4-154995-0. https://apps.who.int/iris/bitstream/handle/ 10665/254637/9789241549950-eng.pdf?sequence $=1$

Yidana SM, Banoeng-Yakubo B, Akabzaa TM (2010) Analysis of groundwater quality using multivariate and spatial analyses in the Keta basin, Ghana. J Afr Earth Sci. https://doi.org/10.1016/j. jafrearsci.2010.03.003

Zaidi FK, Nazzal Y, Jafri MK, Naeem M, Ahmed I (2015) Reverse ion exchange as a major process controlling the groundwater chemistry in an arid environment: a case study from northwestern Saudi Arabia. Environ Monit Assess. https://doi.org/10.1007/ s10661-015-4828-4

Zhu C, Anderson G, Burden DS (2002) Environmental applications of geochemical modeling. Cambridge University Press

Publisher's Note Springer Nature remains neutral with regard to jurisdictional claims in published maps and institutional affiliations. 